\title{
Humanized Mice for Infectious and Neurodegenerative disorders
}

\author{
Prasanta K. Dash', Santhi Gorantla', Larisa Poluektova', Mahmudul Hasan², Emiko Waight' , Chen Zhang ${ }^{1}$, \\ Milica Markovic ${ }^{1}$, Benson Edagwa' ${ }^{1}$, Jatin Machhi ${ }^{1}$, Katherine E. Olson ${ }^{1}$, Xinglong Wang ${ }^{1}$, R. Lee Mosley ${ }^{1}$, \\ Bhavesh Kevadiya ${ }^{1}$ and Howard E. Gendelman ${ }^{1,2^{*}}$
}

\begin{abstract}
Humanized mice model human disease and as such are used commonly for research studies of infectious, degenerative and cancer disorders. Recent models also reflect hematopoiesis, natural immunity, neurobiology, and molecular pathways that influence disease pathobiology. A spectrum of immunodeficient mouse strains permit long-lived human progenitor cell engraftments. The presence of both innate and adaptive immunity enables high levels of human hematolymphoid reconstitution with cell susceptibility to a broad range of microbial infections. These mice also facilitate investigations of human pathobiology, natural disease processes and therapeutic efficacy in a broad spectrum of human disorders. However, a bridge between humans and mice requires a complete understanding of pathogen dose, co-morbidities, disease progression, environment, and genetics which can be mirrored in these mice. These must be considered for understanding of microbial susceptibility, prevention, and disease progression. With known common limitations for access to human tissues, evaluation of metabolic and physiological changes and limitations in large animal numbers, studies in mice prove important in planning human clinical trials. To these ends, this review serves to outline how humanized mice can be used in viral and pharmacologic research emphasizing both current and future studies of viral and neurodegenerative diseases. In all, humanized mouse provides cost-effective, high throughput studies of infection or degeneration in natural pathogen host cells, and the ability to test transmission and eradication of disease.
\end{abstract}

\section{Introduction}

Rodents are the most common animal used in biomedical research laboratories. This is driven largely by low cost, small size, ease of housing, maintenance, large litter sizes and availability of inbred strains. For infectious diseases these animals can be used to study pathogen cell and tissue tropisms, replication, and virulence. Moreover, advances in disease pathogenesis, pharmacologic and vaccine research serves to mitigate the health burden of not simply infectious disease but also metabolic, cancerous, and degenerative disorders [1,2]. Animal models

\footnotetext{
*Correspondence: hegendel@unmc.edu

${ }^{1}$ Department of Pharmacology and Experimental Neuroscience, University of Nebraska Medical Center, Omaha, NE 68198, USA

Full list of author information is available at the end of the article
}

used to study each disease independent of etiology must accurately reflect the clinical and pathological features of the human condition. When those features align, models become indispensable partners in research efforts aimed to better understand pathobiological mechanisms, and hence therapies deployed for translational preclinical investigations. Thus, the needs to better model human disease is essential to accelerate relevant pathogenic and treatment findings or strategies that can be translated to the clinic. The most applicable animal model of human disease closely recapitulates clinical symptoms and disease pathogenesis seen during the disease course. For infectious diseases in particular, the animal model should meet permissibility to the inciting pathogens with a clearly defined route of infection that parallels a

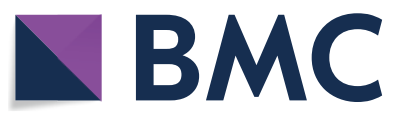

c) The Author(s) 2021. This article is licensed under a Creative Commons Attribution 4.0 International License, which permits use, sharing, adaptation, distribution and reproduction in any medium or format, as long as you give appropriate credit to the original author(s) and the source, provide a link to the Creative Commons licence, and indicate if changes were made. The images or other third party material in this article are included in the article's Creative Commons licence, unless indicated otherwise in a credit line to the material. If material is not included in the article's Creative Commons licence and your intended use is not permitted by statutory regulation or exceeds the permitted use, you will need to obtain permission directly from the copyright holder. To view a copy of this licence, visit http://creativeco mmons.org/licenses/by/4.0/. The Creative Commons Public Domain Dedication waiver (http://creativecommons.org/publicdomain/ zero/1.0/) applies to the data made available in this article, unless otherwise stated in a credit line to the data. 
susceptible human host. Such criteria are imperative for any United States Food and Drug Administration approvals, when and where vaccines and therapeutics cannot ethically be tested on humans. These enable final approvals which can only be made after preclinical tests are completed. The most relevant models' rests in the field of infectious diseases, as many of the studied pathogens are human specific. To such ends, several studies of infectious pathogens can only be completed using humanized mice. Examples include studies of Neisseria meningitides, and when conducted in humanized mice display specificity to human microvessels and induce vascular leakage and tissue necrosis [3]. Leishmania major provides yet another example as infection can proceed in human macrophages with secondary adaptive $\mathrm{T}$ cell responses [4]. Human T cell leukemia virus (HTLV) demonstrate productive infection and expansion of virus specific $\mathrm{CD} 4+\mathrm{T}$ cells [5]. Virus-specific immune responses have also been observed in these humanized mice. Dengue virus infection occurs in the spleen, bone marrow, and liver of humanized mice and these animals develop human disease-like signs and symptoms that include fever, apathy, rash, and weight loss [6,7]. Likewise, Epstein Barr virus (EBV) or human herpes simplex virus type 4 (HHV4) and its associated lymphoproliferative disorders and tumor development are reflected in humanized mice [8]. Kaposi's sarcoma-associated herpesvirus, or HHV8 , leads to persistent latent infection of B cells and macrophages within spleen of humanized mice with viral dissemination to the skin [9]. HHV-2 infections show T and natural killer (NK) cell responses, antibody responses and ongoing viral replication in humanized mice [10]. Human cytomegalovirus (CMV) or HHV-5 can readily be detected in the liver, spleen, and bone marrow of humanized mice [11]. John Cunningham (JC) virus is well studied in humanized mice demonstrating peripheral and central nervous system infection [12, 13]. Salmonella enterica, the causative agent of typhoid fever in humans, can also be investigated in humanized mice [14]. Tuberculosis infections were mirrored in these mice and demonstrate $\mathrm{CD} 4+\mathrm{T}$ cell and macrophage-dependent granuloma-like structure formation after infection [15]. Further treatment with cytokines like, granulocyte macrophage colony stimulating factor (GM-CSF) in these animals demonstrate infection control [15]. Other human diseases such as influenza, Ebola, Hanta virus pulmonary syndrome (HPS), malaria, and sepsis, have been studied using different models of humanized mice, and insights have been gained regarding their severity, transmission and therapeutic efficacy [16].

Other examples of viral and non-viral diseases studied in humanized mice include the human immunodeficiency virus type one (HIV-1) [17], severe acute respiratory syndrome coronavirus 2 (SARS-CoV-2) [18], influenza [19], Zika (ZIKV) [20], hepatitis C (HCV) [21], dengue viruses [19] and malaria [22, 23]. These studies were possible after the research community overcame the limitations imposed by grafting human tissues. Mice lacking a functional adaptive immune system such as the severe combined immunodeficient (SCID) or recombination activating gene 1 (RAG-1) knock-out become permissive to engraftment of human immune cells from human solid organ tissues or cord blood [24]. At the same time, removal of mouse genes like common gamma chain of the interleukin-2 receptor enabled the models to reflect multiple aspects of the human innate and adaptive immune response $[16,17,25]$. In the early 2000 s, the development of immunodeficient mice bearing mutations in the IL-2 receptor gamma chain $\left(I L 2 r g^{\text {null }}\right)$ proved to be a breakthrough in humanized mouse development [26]. The common gamma chain $\left(\gamma_{C}\right)$ represents an important component of receptors for IL-2, IL-4, IL-7, IL-9, IL-15, and IL-21, and is crucial for the signaling of human cytokines. The attenuation of cell cytokine signaling pathways by $\gamma_{C}$ which are involved in the survival, differentiation, and function of lymphocytes impairs the development of the mouse lymphoid system. In combination with either protein kinase DNA activated catalytic polypeptide mutation ( $P r k d c^{s c i d}$ or scid), or with Rag 1 or 2 (Rag1 $1^{\text {null }}$ or Rag $2^{\text {null }}$ ) mutations, adaptive immunity is depleted. These mice also exhibit deficiencies of innate immunity and lack murine NK cells [26].

New therapeutic agents and preventive strategies require in-depth understanding of disease pathobiology. Appropriate model systems are also required for testing the safety and efficacy of disease preventative measures $[27,28]$. Selection of a model to mimic disease is driven by physiologic linkages to humans, ease of use, reproducibility, safety, and cost [27]. Due to limitations associated with non-human primates (NHPs) that include expense, availability, time, and genetic limitations, there is a need for small animal models as human surrogates $[29,30]$. Rodent experiments can assess study reproducibility while controlling host genetics in response to the pathogen or to the disease [28]. Although medically relevant pathogens can cause disease in inbred mouse strains, pathogens such as ZIKA virus, measles virus, Middle East respiratory syndrome coronavirus (MERS$\mathrm{CoV}$ ), human norovirus, and Crimean-Congo hemorrhagic fever viruses do not produce disease in mouse strains [20, 31, 32]. Notably, the genetic differences between mice and humans interfere with a pathogen's ability to elicit human-like disease outcomes in rodents [33-35]. To overcome these limitations, humanized mice were developed to study host-pathogen interactions. Herein, we focus first on new models of humanized mice 
then evaluate their use to study infectious, neurodegenerative, and inflammatory diseases and therapeutics. We also propose new models and extend the utility ranges of existing ones.

\section{Human cell-grafted mice}

In cases where mice are not permissive to microbial infection an alternative is "genetically-modified" mice that can be made by the introduction of human-specific genes or engrafting human organs or cells $[16,25,36$, 37]. Mice cannot be used to study hepatitis $B$ and $C$ virus (HBV and $\mathrm{HCV}$ ), herpes viruses and/or HIV-1 where several genes regulate host range, and thus preclude expression of factors that fully recapitulate and promote disease [38]. Another factor that limits the use of rodent models to recapitulate human disease is in differences between host immune responses [16]. This leads to limitations in engraftment efficiency with high rates of tissue rejection. Both reflect common deficiencies to fully recapitulate antigen-specific immune responses [16]. Despite such limitations, human intestinal xenografted mice have been used successfully to support Entamoeba histolytica infections [25, 39]. These model systems can facilitate studies of pathogen interactions with human cells and tissues [40] serving as important pre-clinical tools for biomedical research [24, 29, 30, 41]. As of today, the three most widely used immunodeficient strains are NOD.Cg-Prkdc ${ }^{\text {scid }} I l 2 r g^{t m 1 W j l}$ (NSG), NODShi.Cg-Prkdcscid Il2rg tm1Sug (NOG), and C;129S4- Rag2 ${ }^{\text {tm1Flv }} I l 2 \mathrm{rg}^{\text {tm1Flv }}$ (commonly referred to as BALB/c-Rag2 $2^{\text {null }} I L 2 r g^{\text {null }}$ mice or BRG) mice [29, 30, 41].

NSG and BRG mice lack the $\gamma_{C}$, whereas NOG mice have a truncated cytoplasmic domain of the gamma chain that binds to cytokines but lacks the signaling domain. These can be deployed for study using four general approaches to engraft a human immune system. The first model is the human peripheral blood leukocyte (PBL) severe immune deficiency (Hu-PBL-SCID) model which is generated by injection of human PBLs, where rapid engraftment of human $\mathrm{CD} 3+\mathrm{T}$ cells occurs within one week. The model allows transient studies of human $\mathrm{T}$ cell function limited by the development of xenogeneic graft-versus-host disease (GVHD) [24]. The second model is the bone marrow/liver/thymus "BLT" model. This is generated by transplantation of human fetal liver and thymus under the kidney capsule and concurrent intravenous injection of autologous fetal liver hematopoietic stem cells (HSCs) [42, 43]. All lineages of human hematopoietic cells are developed, and the model supports a robust mucosal immune system. Human T-cells are educated in an autologous human thymus and are HLA-restricted. Despite these advantages, there are two major drawbacks including GVHD-like reactions [29,
$30,44]$ and limitations in obtaining fetal cells to generate the model. The third model is through the injection of human CD34+HSCs derived from bone marrow (BM), umbilical cord blood, fetal liver, or granulocyte colony-stimulating factor (G-CSF)-mobilized peripheral blood. This model possesses BM-generated T cells, $\mathrm{B}$ cells, antigen-presenting cells (APCs), and myeloid cells, but are found at low levels. The human $\mathrm{T}$ cells are educated in mouse thymus and are $\mathrm{H} 2$ type, not HLArestricted [45]. The fourth model is generated by intrahepatic injection of human CD34+ HSCs from human cord blood [26]. This model supports engraftment of a complete human immune system which lasts for more than one year with limited GVHD and is the most widely used due to reduced manipulation of the mice during their generation. The only disadvantage of this model is that the human $\mathrm{T}$ cells are educated in murine thymus and have functionally underdeveloped lymphatic tissues [46]. Despite these limitations humanized mice are commonly utilized as translational models in regenerative medicine, transplantation immunity, infectious disease research and for cancer biology and therapeutics.

\section{HIV-1 infection, pathogenesis, prevention, and antiretroviral testing}

Species specificity of HIV initially precluded the use of mouse models for HIV infection; however, mice transplanted with functional human immune system (HIS) became a highly versatile and cost-effective model to study HIV-1 disease. Employment of humanized mice for HIV infection started when SCID mice were discovered [47]. Improvements in SCID mice strains have been made by refining the compatibility of mouse innate immune environment to allow human grafts. This has made it possible to have long-term reconstitution of the human immune system that supports chronic HIV infection. Humanized mice can induce adaptive immune responses and have been used, in measure, for vaccine testing [47, 48]. However, the human IgG responses are limited. This has been overcome by employing immunodeficient mice of different backgrounds with HSCs with thymus/liver tissue implants to generate BLT mice $[49,50]$. Different human immune cell subset distribution in blood and lymphoid tissues allows BLT mice to be susceptible to HIV-1 infection. These mice can be infected through natural vaginal, rectal, or intravenous routes and used to study HIV-1 biology (viral entry, replication and spread), virusinduced immunopathology $\left(\mathrm{CD}^{+}{ }^{+} \mathrm{T}\right.$-cell depletion and immune activation), mucosal inflammation, and cellular viral tropism [51-54]. HIV-1 reservoirs can also be established in infected humanized mice after treatment with combinations of antiretroviral drugs (ARVs), thereby providing a model to test new therapies for viral treatment 
and prevention. These mice can also be used to test how best to interrupt viral integration, activation, and replication $[55,56]$. Recently our group employed humanized mice to examine tissue viral reservoirs and to recapitulate latent HIV-1 in vivo $[57,58]$. These works demonstrated that mature macrophages are a cell reservoir in antiretroviral therapy (ART)-suppressed HIV-infected humanized mice [59]. Mice infected with HIV and treated with combination ART achieved complete viral suppression in the peripheral blood, and immune cells were sorted into $T$ lymphocyte subsets and macrophages to quantify HIV RNA and DNA. While CD4+ memory cells were the principal T cell reservoir, integrated HIV-1 DNA was detected in the bone marrow and spleen macrophages. These findings were affirmed in humanized myeloid only mice (MoM) [60].

Existing antiviral medicines are designed to block essential steps of the virus life cycle. To gain access into the host cell, virus particles adsorb and bind to the CD4 and CCR5 or CXCR4 receptor and co-receptor proteins present on the host cell surface. Agents that block these interactions have been developed into effective drugs against HIV-1 [61]. Other antiviral drug targets include ion channel blockers or inhibitors of structural and nonstructural viral proteins, reverse transcriptase enzyme, integrase, protease, and neuraminidase enzymes that catalyze polyprotein cleavage and release of mature virions. However, notable limitations include the narrow spectrum nature of the compounds, suboptimal adherence to daily regimens, poor bioavailability, drug resistance, and associated toxicities. The available antiviral agents are also virus-specific with only a few exhibiting broadspectrum antiviral activities [62]. While development of broad-spectrum antivirals may seem to offer attractive alternatives to conventional target-specific antiviral drugs, their development into drug candidates has been hampered by either poor efficacy or toxicity concerns [63]. Limitations in delivery and failure to maintain therapeutic drug concentrations at sites of viral replication have also negatively impacted therapeutic outcomes. The absence of vaccines for chronic viral infections such as $\mathrm{HIV}$ and $\mathrm{HCV}$ has led to growing interest in long-acting (LA) formulations and devices aimed at improving patient adherence to therapy to minimize emergence of drug resistance [64, 65].

Humanized mice have been used to test newly developed and LA ART, neutralizing antibody, immunotherapeutic, latency re-activating agents, and viral gene editing strategies $[17,66,67]$. An example is the drug 4'-ethynyl-2-fluoro-2'-deoxyadenosine (EFdA), a nucleoside reverse transcriptase inhibitor (NRTI) that was developed in BLT mice. Works demonstrated that
EFdA monotherapy was able to suppress viral replication [68]. Pre-exposure prophylaxis (PrEP) studies with EFdA prevented HIV-1 vaginal and oral transmission in BLT mice. Other LA ART studies were developed of medicines administered once a month. LA nanoformulated integrase inhibitor raltegravir protected humanized mice from repeated high-dose vaginal HIV challenges in a PrEP study [69]. Our own laboratories created LA nanoformulated protease inhibitors then tested them in humanized mice [70]. Nanoformulated atazanavir and ritonavir (nanoATV/r) combination suppressed plasma viral load below the detection level after six weekly doses, and ART cessation resulted in immediate viral rebound [71]. We also decorated nanoATV/r with folic acid for cell-specific targeting and uptake, and three doses given once every other week significantly improved viral suppression in chronically infected humanized mice compared to untargeted nanoATV/r $[72,73]$. Next, we developed state of the art LA slow effective release (LASER) ART using prodrug technology with the ability to prevent or suppress HIV infection for a prolonged period after a single dose administration. New generation LASER ART formulations of cabotegravir and dolutegravir $(\mathrm{CAB}$ and DTG) could prevent and suppress HIV infection. Nanoformulated myristoylated $C A B$ (NMCAB) after a single $45 \mathrm{mg} / \mathrm{kg}$ intramuscular injection, had pharmacokinetic (PK) profiles that were 4 times greater than that recorded for parenteral $\mathrm{CAB}$. In mice, $\mathrm{NMCAB}$ showed significantly higher drug concentration up to one year after one IM injection as compared to current parenteral $\mathrm{CAB}$ formulations [74]. A hydrophobic and lipophilic modified DTG prodrug encapsulated into poloxamer nanoformulations protected humanized mice from the parenteral challenge of HIV-1 for two weeks [75]. Newer formulations of CAB prodrug nanoformulations have increased the apparent halflife of the drug to one year [76]. Humanized mouse models also demonstrate the antiviral effectiveness of broadly neutralizing HIV-1 antibodies [46]. It has been shown that a combination of antibodies can suppress viremia below the limit of detection and target the HIV-1 reservoir. Moreover, passively administered antibodies and vector-mediated expression of broadly neutralizing antibodies protect humanized mice from HIV-1 infection [77]. The mouse models also provide a potential bridge to predict immunotherapeutic-related cytokine release syndrome and development of HIV-1 cure strategies. PBLs from patients can be engrafted in adult immunosuppressed mice to study the response to immunotherapies, like anti-CD3, anti-CD28, Keytruda, anti-thymocyte globulin, and a TGN1412 analog. 


\section{NeuroHIV and humanized mice}

Soon after the discovery of HIV, it was found that mononuclear phagocytes (MP; monocytes, macrophages, microglia, and dendritic cells) are the principal viral targets within the central nervous system (CNS) [78]. HIV enters the brain during early stages of HIV infection, and the infected monocyte-macrophage act as Trojan horses in viral spread within the CNS [79]. For HIV-1 disease in the brain, MPs serve as viral reservoirs and inducers of end-organ disease and are the drivers of HIV-1 associated neurocognitive disorders (HAND), a clinical disease complex prevalent in up to $50 \%$ of infected people [80]. Introduction of ART has been effective in suppressing viral replication and reducing the severity of cognitive, motor, and behavioral impairments [81]. The virus persists in a latent form, and neither ART nor the host antiviral cellular and humoral immunity could eliminate infection leading to milder forms of memory impairments [82, 83]. Virus-induced MP functions lead to the production of cell and viral toxins that reflect an aberrant secretory immune response and persistent low-level infection [84]. Neuroinflammation through persistent glial infection and activation has emerged as a signature phenotype of HAND. Understanding the underlying molecular and cellular mechanisms in HAND pathology and viral persistence is essential to develop therapeutic strategies for HAND and for HIV elimination from CNS. While studies of the simian Immunodeficiency virus (SIV) have contributed to the current knowledge of HAND, the need for more scalable and affordable models lead to the initial development of a mouse model of neuroHIV in the 1990s [85]. Since HIV-infected MPs are the major drivers of HAND-associated pathology, human virus-infected monocyte-derived macrophages were injected intracerebrally into the caudate-putamen of immunodeficient mice [52, 86, 87]. Several important aspects of HIV-1 encephalitis (HIVE, the pathological equivalent of advanced virus-associated cognitive dysfunction) such as multinucleated giant cell pathology, activated microglia and astrocytes, myelin pallor, and dendritic loss were observed. Moreover, behavioral, and cognitive abnormalities in the HIVE mice were associated with neuronal dysfunction and decreased synaptic density. The HIVE mouse model has been used to test anti-inflammatory, antiretroviral, or neuroprotective therapeutic approaches [86]. Initial studies in this model provided a direction in understanding efficient ART regimens to suppress viral load in the HIV infected brain.

Further improvements to include the adaptive immune component of HIV infection in neuroHIV was achieved by the reconstitution of immunodeficient animals with syngeneic human peripheral blood lymphocytes followed by intracranial injection of HIV-1-infected macrophages resulted in cytotoxic antivirus $\mathrm{T}$ lymphocyte (CTL) response [88]. CD8-positive $\mathrm{T}$ cells migrated to the sites of human macrophages leading to the cell-mediated destruction of HIV-1 infected cells. Development of HIVE mice reconstituted with a human immune system enabled testing of immunomodulators that included indoleamine 2,3-dioxygenase (IDO) inhibitors, peroxisome proliferator-activated receptor (PPAR) gamma, and cannabinoid 2 (CB2) receptor agonists [88]. The major limitations of the HIVE mouse models are associated with traumatic injury caused by the cell injections into the brain, focal neuropathology around the injected area and an imperfect relationship between the brain neuropathology and progressive systemic infection. Moreover, the HIVE and AIDS dementia complex was prevalent during pre-ART era and modeling milder forms of HAND requires mice that can be chronically infected with HIV and with suppressive ART.

Mice reconstituted with human immune system allowed to study chronic HIV infection, however, a limitation in humanized mouse models involves the distribution of human cells in the brain. Human cells are located mainly in the meninges; with very few in perivascular areas and brain parenchyma. Moreover, human microglial-like cells are rarely found in the mouse brain. HIV-infected human macrophages and lymphocytes are mainly found in meninges and perivascular areas [87, $89,90]$. Longitudinal non-invasive imaging studies using diffusion tensor imaging (DTI) and magnetic resonance spectroscopy (MRS) revealed progressive loss of neuronal integrity, which correlated with gliosis and loss of neuronal dendritic and synaptic proteins and myelin [91]. Behavioral abnormalities such as memory loss and anxiety were also observed in HIV-1 infected humanized mice [91]. HIV related behavioral deficits were mostly studied in non-humanized rodent models, including HIV transgenic rodents [92-97] and EcoHIV infected mice [98-100].

Humanized MoM reconstituted with human myeloid and $\mathrm{B}$ cells, but no $\mathrm{T}$ cells, showed productive infection of HIV-1 in MPs and led to the viral seeding in CNS by infected MPs [60]. Presence of both classical and intermediate macrophages were observed in the brains of MoM, but the lack of human microglia limited productive brain infection. In a humanized $\mathrm{T}$ cell only mouse, $\mathrm{T}$ cells could also establish and maintain HIV infection in the CNS [101]. Nonetheless, in all the humanized mouse models, HIV brain infection is minimal due to the limited number of human cells [102].

As noted, MPs are the major cellular targets for HIV-1 in brain, human astrocytes can be infected but at very low levels [103, 104]. Both microglia and astrocytes contribute to the CNS viral reservoir and neuroinflammation. 
To utilize the humanized mice for neuroHIV studies, the presence of human glia in the mouse brain along with the human immune system are necessary. The ability to reconstitute the murine brain with functional human glial cells would provide an opportunity to study HIV induced inflammation, neuronal dysfunction, and viral reservoirs in one system. Our laboratories generated a humanized mouse model dually reconstituted with human astrocytes and human leukocytes [105]. By transplanting human neuroprogenitor cells in the brain and HSC in the liver simultaneously in a new-born mouse, led to the development of human astrocytes and leukocytes. In these mice human glial-specific anti-viral response was observed following systemic HIV infection, and the neuropathogenesis was observed as downregulation of mouse genes crucial for oligodendrocyte differentiation and myelination, suggesting alterations in structure and function of white matter. HIV brain infection was minimal in this model, again restricted to macrophages and lymphocytes in meninges, and very few perivascular and parenchymal human leuokocytes, due to the lack of human microglial reconstitution. To facilitate human microglial differentiation in HSC-transplanted humanized mice, IL-34, a tissue specific ligand for colony stimulating factor-1 receptor (CSF-1R), was transgenically introduced into immunodeficient mouse strain (Fig. 1). IL-34 is important for human microglial and tissue macrophage development. Human HSC reconstitution in human IL-34 transgenic immune deficient mice lead to the engraftment of a mouse brain with human microglia that expressed canonical markers such as CD14, CD68, CD163, CD11b, ITGB2, CX3CR1, CSFR1, TREM2, and P2RY12 [106]. Peripheral HIV infection led to productive infection of human microglia with a significant number of HIV-1 antigen positive cells distributed in all mouse brain regions. Human-specific molecular signatures representative of antiviral and neuroinflammatory responses were detected. Transcripts for all viral proteins were readily identified with the highest expression of HIV env, pol and nef. Further, neuropathological assessments during HIV infection are under investigation. Our recent studies using human microglia mouse model demonstrated significant levels of HIV-1 DNA in the brain and other lymphoid tissues even under combination ART controlled viral infection supporting the establishment of CNS viral reservoirs in mice. These improved humanized glial mouse models permit investigations of neuroHIV in presence of suppressive ART. Further studies of HIV induced neuropathology and behavioral deficits in HIV infected and ARV treated humanized microglial mice will provide a better understanding of the human disease and the underlying molecular mechanisms for successful therapeutic development. This new model to study HIV

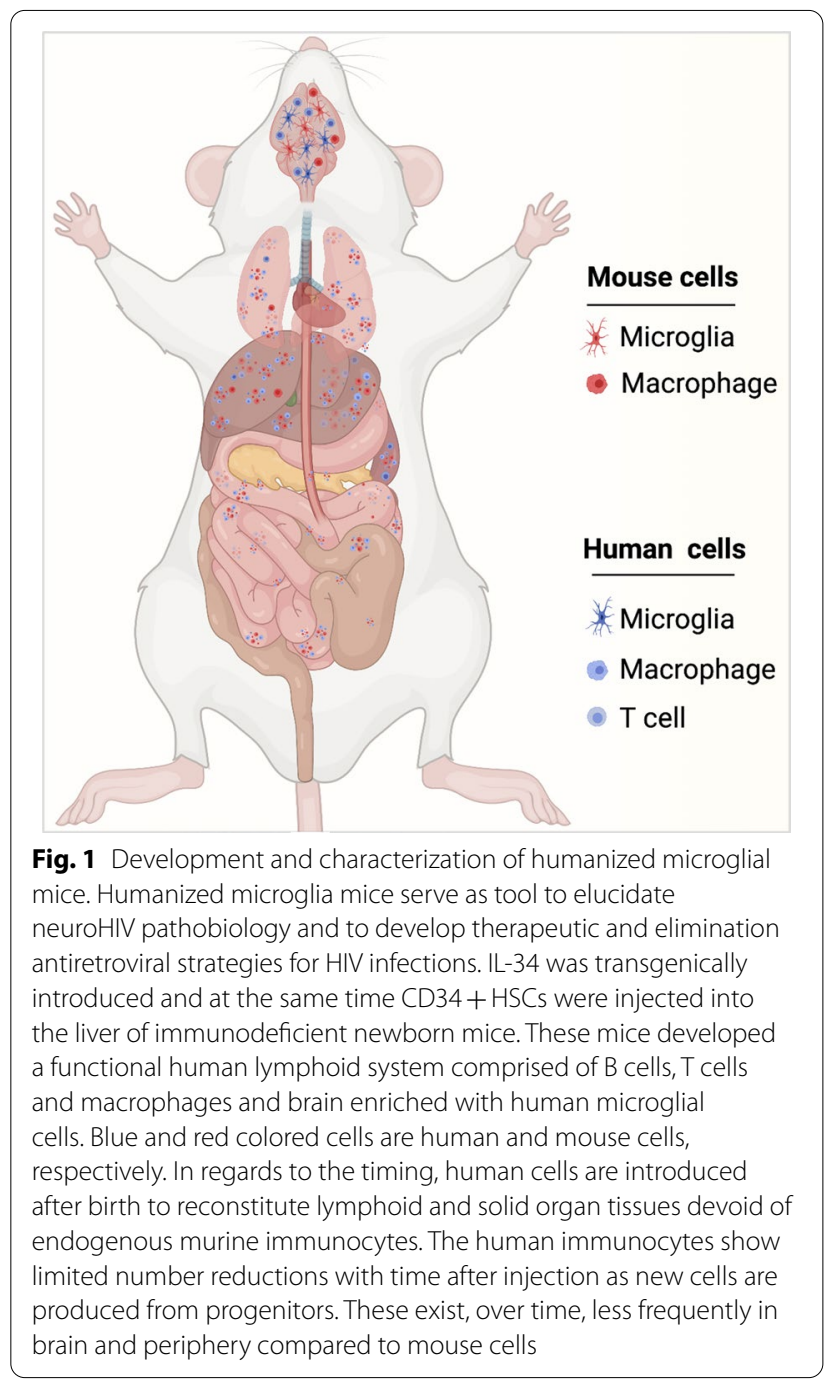

brain infection also aid in the development and testing of new generation ART delivery with improved CNS bioavailability and will be useful for future viral eradication studies. Further, the model now allows studies of newly emerging ART-induced neurotoxicity such as reported for efavirenz [107, 108]. However, many laboratory and animal studies have shown a number of direct effects on neuronal and glial function along with pathological outcomes that are linked to amyloid deposition, small vessel damage and aberrations in chemical neurotransmission [109-114]. Studies of macrophage function as part of depot for sustained release agents are now possible with these newer humanized mouse models [59, 105, 115-118]. Perhaps ever more important rests in the need of vigorous behavioral testing which have been initiated in the earlier models but remain underdeveloped in these humanized microglial brain test systems [106, 119]. 


\section{Hepatitis B}

It is estimated that approximately two billion people worldwide have evidence of past or present infection with hepatitis B virus (HBV), and 257 million individuals are chronic carriers (i.e., positive for hepatitis B surface antigen [HBsAg]). The rate of progression from acute to chronic $\mathrm{HBV}$ infection (CHB) is approximately $90 \%$ for perinatally-acquired infection, however vaccination has reduced the progression by $90 \%$ [120]. A significant proportion of people living with HIV-1 are also infected with HBV [121, 122]. However, the number of existing $\mathrm{CHB}$ patients exceed number of people living with HIV-1 [64]. The progression of CHB leads to the development of cirrhosis and hepatocellular cancer [123]. $\mathrm{CHB}$ remains a significant burden on health care system around the world and requires effective treatment to prevent progression [21]. The goal for $\mathrm{CHB}$ patients is to achieve a cure, however the complexity of the viral life cycle and multiple mechanisms of avoidance of immune responses cause complications. The formation of stable covalently closed circular DNA (cccDNA) as a replication template of HBV also represents a significant challenge for elimination. The elimination of hepatocytes with integrated HBV genome is immune mediated and required for clearance of $\mathrm{HBsAg}$. All steps in HBV lifecycle are present in human hepatocytes, and humanized mice are an instrumental tool to evaluate the efficacy and safety of available therapeutics. Several models are reported to humanize the mouse liver and establish HBV infection [124]. Human liver chimeric mice are often generated using the urokinase-type plasminogen activator transgene (uPA) and RAG-2 gene knockout (uPA/ $\mathrm{RAG}^{-/-}$) mice[125]; uPA/SCID [126], mice deficient in the tyrosine catabolic enzyme fumarylacetoacetate hydrolase $\left(\mathrm{Fah}^{-/-}\right.$) on $\mathrm{Rag} 2^{-/-}$interleukin 2 receptor gamma chain knockout (Il2 $\mathrm{rg}^{-/-}$) mice (FRG) [127], and herpes simplex virus type-1 thymidine kinase- NOD/ Shi-scid IL2r-gamma(null) NOG (TK-NOG) mice [128]. Different levels of liver humanization can be achieved in these models and different strains of HBV (and hepatitis delta virus) that can naturally infect human hepatocytes. The established chronic HBV viremia $\left(10^{5}-10^{10} \mathrm{IU} / \mathrm{mL}\right.$ HBV DNA) and HBsAg stable expression presence in circulation, are used to monitor treatment efficacy and liver tissues for evaluation of cccDNA copies. The use of chimeric mice for anti-HBV therapeutics are described in detail [129].

Existing treatment of $\mathrm{CHB}$ is based on inhibition of viral RNA reverse transcription to prevent replenishment of cccDNA by nucleot(s)ides (NAs), which requires a life-long administration of oral drugs with strong adherence. Entecavir remains the most used oral therapeutic in humanized mice experimental combinatorial treatments [130]. LA lamivudine nanoformulation was developed by our laboratories and tested on humanized mice. A single intramuscular injection of $75 \mathrm{mg} /$ $\mathrm{kg}$ reduced HBV DNA in peripheral blood for up to 2.5 $\log$ for 4 weeks [115]. The differences of HBV genotypes and drug-resistant mutants (to entecavir and lamivudine) susceptibility to $90 \mathrm{mg} / \mathrm{kg}$ body weight/day of TDF for 3 weeks were tested on uPA/scid mice [131]. The effects of NAs to inhibit reverse transcription and HBV DNA synthesis and antiviral properties of IFN- $\alpha$ showing enhanced cccDNA degradation were fully reproduced in humanized liver mice [132]. IFN- $\alpha$-mediated suppression of HBsAg concentration and silencing of cccDNA was extensively studied on uPA/scid and uPA/scid/IL2Rgc-/(USG) liver humanized mice $[133,134]$. The effective new approaches targeting $\mathrm{HBsAg}$ that tolerates the immune system and support viral persistence were assessed in humanized liver mice. ARB-1740 is a clinical stage RNA interference agent composed of three siRNAs delivered using lipid nanoparticle technology (LNP). A combination of ARB-1740 with a capsid inhibitor and pegylated interferon-alpha led to greater liver HBsAg reduction which correlated with more robust induction of innate immune responses in cDNA-uPA/scid human chimeric mouse model of HBV $[135,136]$.

The lipid nanoparticles (LNPs) containing HBsAg silencing RNA were modified with a hepatocyte-specific ligand, $\mathrm{N}$-acetyl-d-galactosamine (GalNAc) and tested on chimeric uPA/scid mice [137]. Modification of the GalNAc-LNPs with polyethyleneglycol negated the LNP-associated toxicity without any detectable loss of gene silencing activity in hepatocytes. A single injection of the modified LNPs resulted in a significant reduction of HBV genomic DNA and their antigens [137]. Multiple approaches targeting capsid proteins were tested on chimeric humanized mice. For example, ciclopirox, a synthetic antifungal agent, inhibits HBV capsid assembly and secretion of HBV DNA in infected liver chimeric uPA/scid mice alone or synergized by Tenofovir disoproxil fumarate (TDF) (six weeks orally) [138]. GLP-26, a novel glyoxamide derivative that alters HBV nucleocapsid assembly and prevents viral DNA replication, in combinatorial treatment with entecavir in a humanized mouse model showed reduction in viral load and viral antigens, which was sustained for up to 12 weeks after treatment cessation [139]. Humanized uPA/scid mice were also used to evaluate NVR3-778, a capsid assembly modulator, in combination with PEG-IFN, and showed positive effect as compared with entecavir [140]. The adeno-associated virus (AAV) vectors and CRISPR-Staphylococcus aureus (Sa)Cas9 were used to edit the HBV genome in liver-humanized FRG mice chronically infected with $\mathrm{HBV}$ and treated with entecavir, which showed reduction 
in total liver HBV DNA and cccDNA [141]. Similar studies of anti-HBV effects of the AAV2-/WJ11-Cas9 system in a uPA/scid humanized chimeric mouse model also showed reduced HBV infection [142].

Humanized liver mice were also used to assess the efficacy of cellular immune-mediated elimination of HBV infected human hepatocytes. For example, transplantation of USG mice with human HLA-A2-positive hepatocytes enables testing of cytotoxic $\mathrm{T}$ lymphocyte-mediated activity. The engineered $\mathrm{T}$ cell receptors recognize $\mathrm{HBV}$ core and HBsAg-derived peptides and then eliminate HBV infected cells reducing viremia [143]. This approach was tested in combination with Myrcludex B, which prevents HBV entry. The adoptive transfer of PreS1 antibodies prevented, or modulated, HBV infection after a subsequent challenge of the virus in humanized uPA/ scid mice for 3 to 8 weeks [144]. In addition to listed complex approaches, long-acting formulations of existing NAs with activities against HBV have great potential to end the HBV epidemic, and humanized mouse models are better suited for the advancement in studying such formulations.

\section{Viral cure strategies and humanized mice}

Viral infections constitute a major public health threat that underscore the need for innovative approaches and preparedness to combat pandemics. Treatments with antiviral drugs are used to limit the severity of illness without eliminating the virus from the host cells. While vaccines would be ideal in combating infections, rapid viral mutations and heterogeneity have posed significant challenges with only a few effective vaccines available for a limited number of viruses [61]. For instance, the high genetic variability and immune escape exhibited by HIV and other RNA viruses such as HCV have impeded the development of safe and effective vaccines against all types and subtypes of the pathogen. These limitations highlight the need for development of effective interventions that target multiple replication pathways to be tested in appropriate animal model systems.

CRISPR-Cas based genome editing represent a novel tool that has wide-ranging applications in the treatment of various infectious and neurodegenerative diseases $[145,146]$ and can be used to insert, delete or modify target genes with very high precision and accuracy $[147,148]$. CRISPR Cas allows for precisely edited mouse models and opens doors of unlimited possibilities. CRISPR-Cas can be used in humanized mouse models to advance the treatment of diseases like cancer, diabetes, viral and nonviral infectious diseases. Hemophilia A patient-derived pluripotent stem cells were edited ex-vivo using CRISPR and then transplanted into the hind limb of hemophilia mice, increased survival of the mice was observed [149]. Similar approaches have been employed for other hematological abnormalities. The ability of CRISPR to make edits ranging from a single base to the insertion of long sections of DNA opens the door for humanized mouse models where mouse genes are replaced with human genes at multiple loci [150] and will improve humanized mouse models for neurodegenerative diseases [151]. Using a combination of LASER ART and CRISPR-Cas9 HIV excision strategies, our group recently achieved HIV eradication in a subset of HIV infected humanized mice [152]. This is the first study of its kind demonstrating HIV elimination from infected animals (Fig. 2). CRISPR-Cas9 has been proposed as a means of mimicking the CCR5 delta 32 mutations that provides a small percentage of the human population resistance against HIV infection. Human primary $\mathrm{CD} 4^{+} \mathrm{T}$ cells were expanded then transduced with lentivirus delivering CRISPR-Cas9 against CCR5. After the CCR5 modification was confirmed, these cells were transplanted in a NOD-Prkdc ${ }^{\mathrm{em} 26 \mathrm{Cd} 52} \mathrm{Il} 2 \mathrm{rg}^{\mathrm{em} 26 \mathrm{Cd} 22} / \mathrm{Nju}$ mice and reconstituted mice challenged with HIV-1. These animals displayed some degree of resistance but failed to provide complete protection against HIV [153]. Use of preclinical mouse models and proper screening can provide a better solution to study infectious diseases and to find cure.

\section{Neurodegenerative diseases and future employments of humanized mice}

\section{Alzheimer's disease}

Alzheimer's disease (AD) is the most common neurodegenerative disease affecting the elderly population and is the sixth leading cause of death in the United States [154, 155]. Promising outcomes in preclinical studies have not always yielded positive clinical outcomes [156]. Recent advancements have revealed that current animal models lack important biological features and therefore are unable to mimic human disease pathology precisely. AD researchers have commonly used first-generation transgenic mouse models that overexpress proteins linked to familial $A D$, mutant amyloid precursor protein (APP), or APP and presenilin. While these mice can demonstrate $\mathrm{AD}$ pathology the animal models lack important biological features and therefore are unable to mimic human disease pathology precisely. This has given rise to second-generation mouse models which contain humanized sequences and clinical mutations in the endogenous mouse App gene. Thus, limitations of first-generation animal models are now successfully overcome by the development of humanized knock-in mice as secondgeneration models [157]. Human and mouse immune and neuronal cells are different at the transcriptional levels, therefore, offer differential responses against $\mathrm{AD}$ 


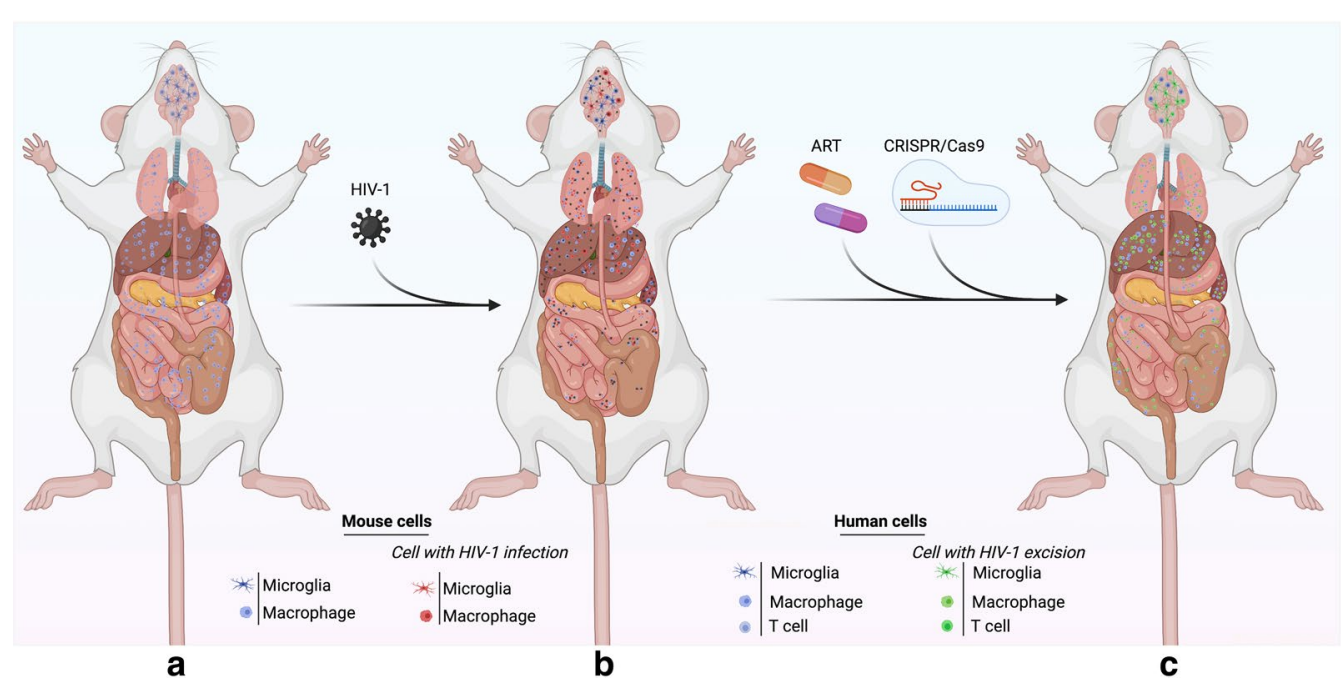

Fig. 2 LASER ART and CRISPR-Cas9 therapies for HIV-1 elimination. Humanized mice developed (a) and HIV-1 infected humanized (b) mice were administered with sequential treatment of a combination of long-acting ART followed by CRISPR-Cas9 targeting specific sequences of the HIV-1 genome (c). Using sequential treatments, complete HIV-1 elimination from a subset of animals. This combinatorial approach is being developed for improved delivery of CRISPR-Cas9 to target the latent reservoirs in humanized mouse models (left panel), to improve the rates of viral elimination (right panel) (Color explanation: blue color cells are represented as human cells, red color cells are represented HIV-1 infected cells and green color represents the cells with complete elimitation of HIV-1)

pathological proteins, which can affect the efficacy of therapeutic candidates in clinical testing $[158,159]$. With field advancement, human-induced pluripotent stem cells have been transplanted into the mouse brain, allowing for study on how amyloid pathology affects human neurons in the context of a multicellular brain environment [160]. Additionally, transplantation of humaninduced pluripotent stem cells into immunodeficient mice allowed development of human microglia cells, which interact with $\mathrm{A} \beta$ differently compared to the other humanized mouse counterpart [161]. Our laboratory recently developed human IL-34 transgenic mice under immunodeficient genetic background, where upon transplantation of human hematopoietic stem cells resulted in human-like microglia cells development in the brain [106]. The human adaptive immune response is different from those mice $[162,163]$, which further affects APP expression and $A \beta$ accumulation. Therefore, with the emerging role of the innate and adaptive immune arm in $\mathrm{AD}$ pathogenesis and their differential regulation in two different species, the urgent development is needed for better small animal models with the complete human immune system.

\section{Parkinson's disease}

The defining characteristic of Parkinson's disease (PD) is the progressive loss of dopaminergic neurons originating in the substantia nigra ( $\mathrm{SNpc}$ ) and innervating to the striatum resulting in the concomitant loss of dopamine, the principal movement-controlling neurotransmitter $[164,165]$. This loss leads to the progressive development of primary motor dysfunction and deficits, including resting tremor, bradykinesia, muscle rigidity, and postural instability. PD hallmarks include neuronal Lewy body inclusions that are comprised primarily of misfolded, oligomerized $\alpha$-synuclein ( $\alpha$-syn), and histological evidence of neuroinflammation as indicated by reactive microglia encompassing regions of $\alpha$-syn aggregation and neurodegeneration [166-169].

Rodent models of PD have been utilized to evaluate immunomodulatory agents that target various inflection points along the neuroinflammatory pathway. However, whether pro-inflammatory models that do not include human components as targets will provide sufficient robustness to bring translational therapeutics to completion has been contentious. To determine the acuity of the human immune system in a PD model, NSG mice were reconstituted with human CD34+HSCs, and were considered engrafted with at least $25 \% \mathrm{HuCD} 45+$ peripheral mononuclear cells (PMNCs) by 12 weeks post-reconstitution [170]. Engrafted mice and age-matched wild type mice were treated with three doses of 1-methy-4-phenyl1,2,3,6-tetrahydropyridine (MPTP), a neurotoxin known to cause PD like symptoms, at $18 \mathrm{mg} / \mathrm{kg} / \mathrm{dose}$ every two hours. One MPTP-treated group from each strain was treated with tacrolimus (FK506), a calcineurin/NFAT 
inhibitor that suppresses T-lymphocyte signal transduction pathways and IL2 transcription and is indicated for organ transplantation and ulcerative colitis [171, 172]. Previous studies demonstrated that FK506 reduced $\alpha$-syn aggregation and microglial activation with subsequent neuroprotection in animal models of PD, including MPTP- and $\alpha$-syn overexpression-induced dopaminergic neurodegeneration [173-175]. Utilizing MPTP, this study provided the first demonstration of induced PD-like lesions and motor deficits in humanized CD34+mice [170]. Of note, treatment of humanized mice with MPTP/ FK506 resulted in enhanced survival of dopaminergic neurons in the $\mathrm{SN}$ and efferent striatal termini, whereas less survival was demonstrated in MPTP/FK506-treated wild type mice. As expected, MPTP increased levels of human cytokines, and FK506 treatment diminished levels of most human cytokines in plasma from MPTPtreated humanized mice, whereas only levels of human IL-4, IL-6, IL-8, and IL-12 were diminished from striatal tissues. Interestingly, FK506 treatment did not significantly affect levels of mouse cytokines from plasma or striatum compared to MPTP-treated wild type animals. This suggests that the humanized mouse platform may provide a more robust model for evaluation of translatable therapeutics in rodent models of PD. However, it should be noted that few CNS-infiltrating macrophages/ microglia were of human origin as evidenced by low levels of expression of HuCD45, HLA-DR, and human CD68 in the CNS compared to the peripheral tissues. Additionally, the strains of the mice were of disparate backgrounds with humanized mice derived from the NOD/ShiLtJ compared to C57Bl/6 mice as wild types. Moreover, this study utilized female mice, whereas most MPTP studies are performed in male mice to reduce known variability observed with females. With the advent of ART for HIV-1 treatment, individuals living with HIV have longer lives with fewer co-morbidities, yet still can exhibit motor deficits like PD [176-180]. Thus, a major, yet recurrent question is whether HIV infection affects the development of PD-linked neurodegeneration. To address that question, we investigated the effect of HIV infection on nigrostriatal dopaminergic neurodegeneration [181]. We initially used NSG mice reconstituted with CD34 + human HSCs that could engraft for 18 weeks to attain humanized mice with high levels of CD45 + cells. Humanized mice were infected for three weeks with HIV-1 prior to intoxication with four doses of MPTP at $14 \mathrm{mg} / \mathrm{kg} / \mathrm{dose}$ every two hours. This study showed that in the MPTP model, acute HIV infection afforded no discernable susceptibility to dopaminergic neurodegeneration as demonstrated by insignificant differences of tyrosine hydroxylase $(\mathrm{TH})+$ neuronal loss in the $\mathrm{SN}$ that ranged from 13 to $27 \%$ and losses of striatal termini of $46 \%$ to $53 \%$. Moreover, levels of microglia from HIV/ MPTP were not significantly elevated regardless of HIV infection duration. Thus, these findings indicated either the lack of a synergistic effect, lack of interaction between the reconstituted human lymphocytes and murine microglia within the humanized system, or the inability of HIV to sufficiently infect mouse microglial cells. The limited loss of dopaminergic neurons is most likely due to the initial neurotoxicity associated with MPTP, rather than the ensuing inflammatory cascade linked to immune activation. Therefore, lack of a neurodegenerative phenotype associated with MPTP use in humanized, male mice may indicate the need for experimentation in a different rodent model of PD, such as $\alpha$-syn overexpression or the requirement of better CNS reconstitution of human microglial cells. As novel therapeutic strategies are developed, humanized animal models of neurodegenerative diseases (Fig. 3) are strongly needed to accelerate translation from preclinical to clinical setting [106, 182, 183]. There are obvious strengths, restrictions and opportunities of modeling functional and behavioral deficits associated with neurodegenerative disorders using humanized mice models. First, when fully developed such models would allow investigations of functional neuronal deficts that link to behavioral outcomes in the context of a functional human immune system. Second, neurological disorders may be modeled more exactly as the role of both innate and adaptive immunity comes more significant in disease pathobiology. Third, a clear understanding of the role human immunity plays at the neurobiochemical levels can be uncovered and especially those that predict behavioral insufficiencies and vice versa. Especially in the case of PD where gait and locomotor abnormalities have been well-characterized in prior rodent models these can now be fully explored in the context of human $\mathrm{T}$ cell functions and immune tolerance [170, 184-187]. While motor deficits in the humanized CD34+ mice have been described behavioral comparisons between established rodent models and humanized models await future studies in these exciting models reflective a broad range of human infectious and degenerative diseases [186].

\section{Conclusions}

Humanized mice represent the mainstream of available small animal models used to reflect the pathobiology and developmental therapeutics for human infectious, GVHD, cancerous and degenerative diseases. CD34 mouse models are employed in a variety of platforms seeking drug safety and efficiency and especially those that can modulate the immune system. Altogether, exhaustive research performed from multiple 


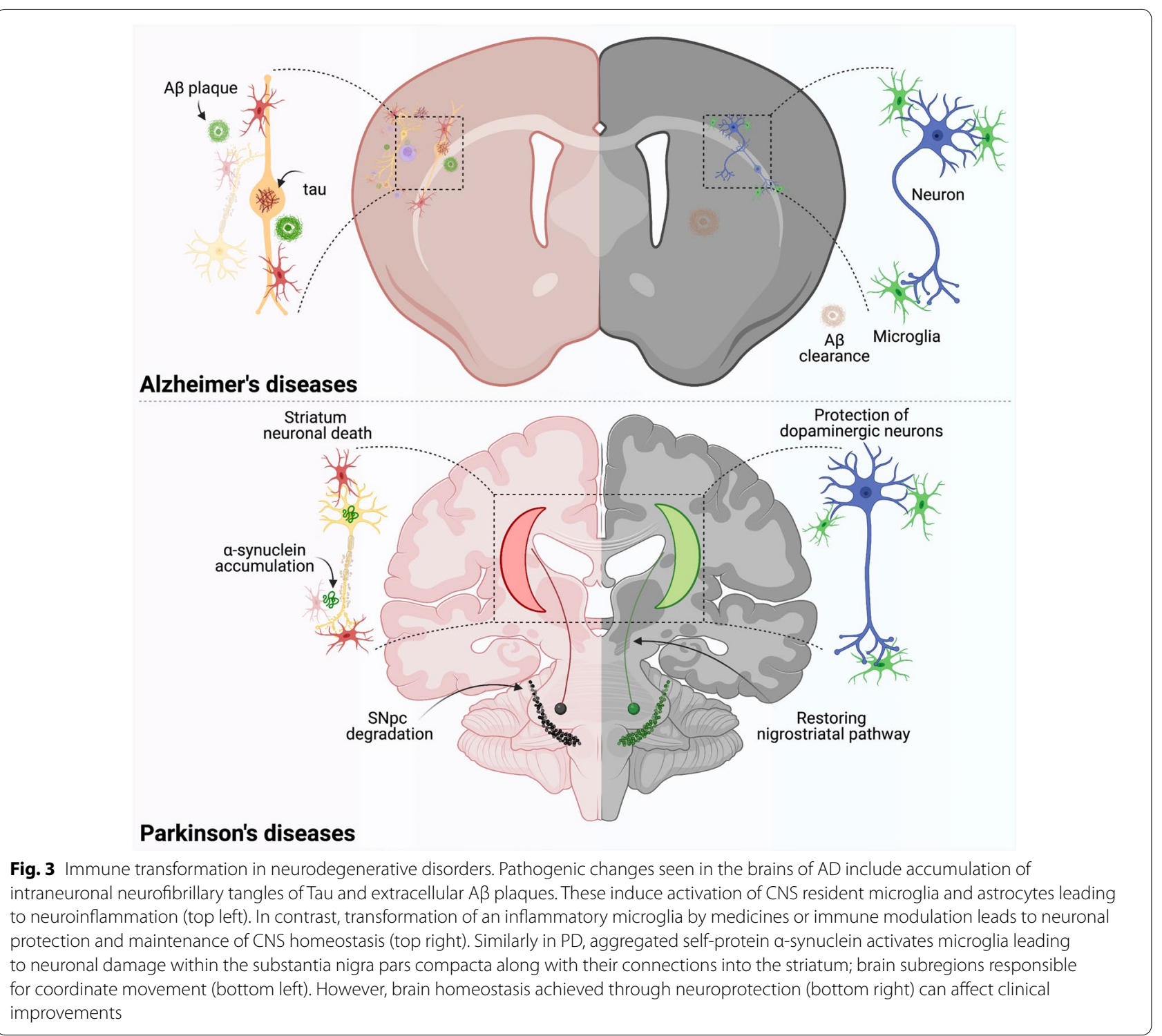

laboratories continues to identify and develop novel disease-modifying treatment options for viral, non-viral and neurodegenerative disease. The pace of the therapeutic development strongly relies on the quality and optimization of preclinical models. Hence, such models can ensure improved translation of various hopeful preclinical results into interventions that will ultimately benefit patients. To this end, we are pleased to provide an example from our own laboratories in the field of LA ART. Herein humanized mice were used to test efficacy, safety, and pharmacokinetics that have sped the development of our year long NM2CAB nano formulation. From these early works in mice, we were able to decipher dose, biocompatibility, cell and tissue drug distribution, immune responses, dissolution parameters and antiretroviral effectiveness. For the NM2CAB we found the prodrug nano formulation to be sustained in a muscle depot then disseminate to the lymphoid system and solid organs with slow-release rates that lead to an extended half-life. Phase 1 clinical trials are now being planned because of these early mouse experiments that facilitated development and safety of these new formulations (Fig. 4). However, this is yet one single example of the promise of human translation by having the ability to mimic human disease processes in a small animal. To that the best is still yet to come. 


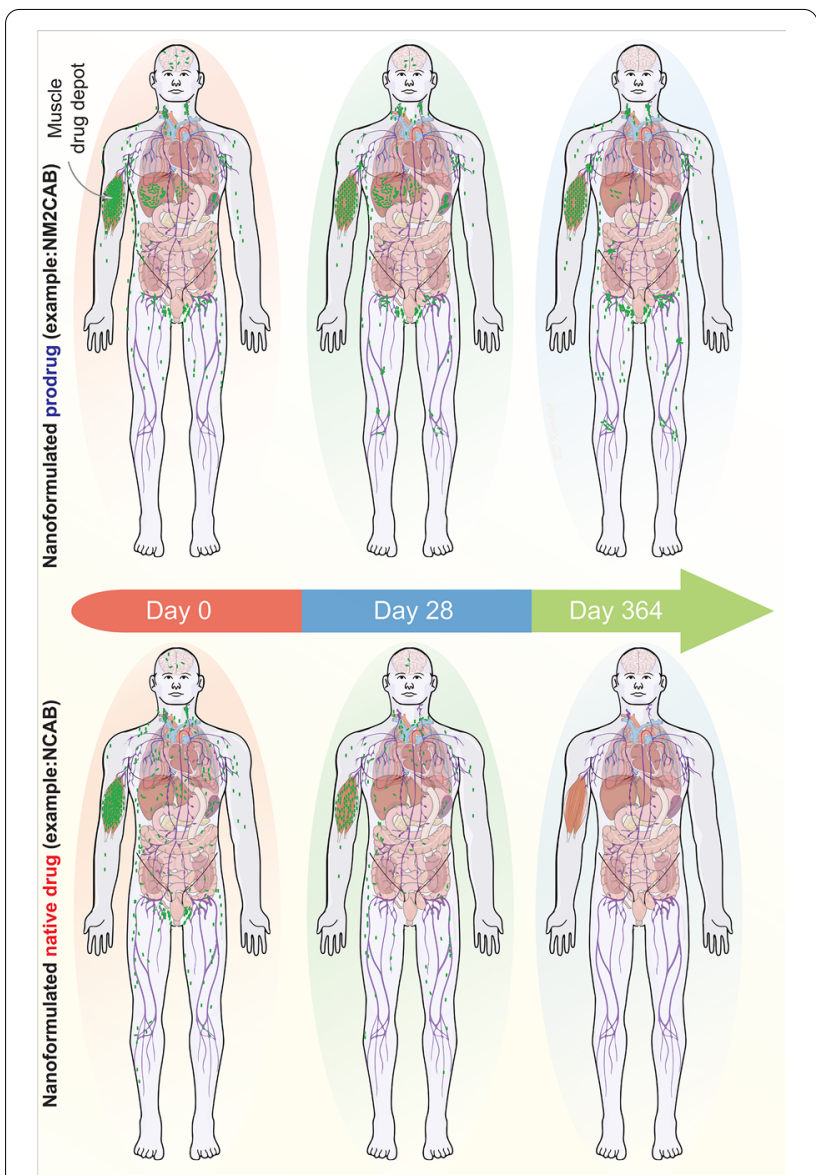

Fig. 4 Potential of LASER ART for HIV-1 treatment and prevention. Based on extensive animal modeling, a single intramuscular injection of a nanoformulated stearoylated CAB ester prodrug (NM2CAB) can lead to sustained drug levels at the site of injection and within the reticuloendothelial system for up to one year (top panel). The formed $C A B$ nanocrystals are absorbed from the injection site and undergo dissolution for prodrug that is subsequently hydrolyzed into active $C A B$ in blood and tissue. CAB prodrug was recorded in all the tissues during a year-long observation in rodents and rhesus macaques after a singleNM2CAB injection. Top panel reflects how NM2CAB can be distributed after an intramuscular injection. By contrast, the nanoformulated NCAB is rapidly cleared from the site of injection and tissues. For NCAB, therapeutic drug levels are present in lymphoid tissues for one month (bottom panel)

\section{Abbreviations}

RT: Reverse transcriptase; HTLV: Human T cell leukemia virus; ART: Antiretroviral therapy; FDA: Food and Drug Administration; HIV: Human Immunodeficiency virus; NNRTI: Non-nucleoside reverse transcriptase inhibitor; NRTI: Nucleoside reverse transcriptase inhibitors; PR: Protease; ISNI: Integrase Strand Transfer Inhibitor; CAB: Cabotegravir; DTG: Dolutegravir.

\section{Acknowledgements}

Not applicable.

\section{Authors' contributions}

PKD co-wrote the paper, organized the presentation and references and edited the manuscript. BK developed, edited, and prepared the figures and captions. HEG conceived, organized, co-wrote, and edited the paper. SG, LP,
$\mathrm{MH}, \mathrm{EW}, \mathrm{CZ}, \mathrm{MM}, \mathrm{BE}, \mathrm{JM}, \mathrm{KEO}, \mathrm{XW}, \mathrm{RLM}$ co-wrote and edited the manuscript. All authors have read and approved the final version of the paper. All authors read and approved the final manuscript.

\section{Funding}

This work was supported by National institute of Health $(\mathrm{NIH})$ grants R01 MH121402-01A1, R01 MH121402P01, R01 AG043540, R01 AG043530, P01 DA028555, P30 MH062261, R01 MH1 15860, R01 NS034249, R01 NS036126, R24OD018546 and the Carol Swartz Emerging Neuroscience Fund and the Margaret R. Larson Professorship. The funders have no role in the preparation of this article.

\section{Availability of data and materials}

Not applicable.

\section{Declarations}

\section{Ethics approval and consent to participate}

Not applicable.

\section{Consent for publication}

Not applicable.

\section{Competing interests}

BE and HEG are co-founders of Exavir Therapeutics, Inc, a company formed to developed extended action antiretroviral drug therapies.

\section{Author details}

1 Department of Pharmacology and Experimental Neuroscience, University of Nebraska Medical Center, Omaha, NE 68198, USA. Department of Pharmaceutical Sciences, University of Nebraska Medical Center, Omaha, NE 68198, USA.

Received: 16 April 2021 Accepted: 22 May 2021

Published online: 05 June 2021

\section{References}

1. Goncalves BC, Lopes Barbosa MG, Silva Olak AP, Belebecha Terezo N, Nishi L, Watanabe MA, Marinello P, Zendrini Rechenchoski D, Dejato Rocha SP, Faccin-Galhardi LC. Antiviral therapies: advances and perspectives. Fundam Clin Pharmacol. 2021;35:305-20.

2. Pardi N, Weissman D. Development of vaccines and antivirals for combating viral pandemics. Nat Biomed Eng. 2020;4:1128-33.

3. Melican K, Aubey F, Dumenil G. Humanized mouse model to study bacterial infections targeting the microvasculature. J Vis Exp. 2014. https:// doi.org/10.3791/51134.

4. Wege AK, Florian C, Ernst W, Zimara N, Schleicher U, Hanses F, Schmid M, Ritter U. Leishmania major infection in humanized mice induces systemic infection and provokes a nonprotective human immune response. PLoS Negl Trop Dis. 2012;6:e1741.

5. Tezuka K, Xun R, Tei M, Ueno T, Tanaka M, Takenouchi N, Fujisawa J. An animal model of adult T-cell leukemia: humanized mice with HTLV1-specific immunity. Blood. 2014;123:346-55.

6. Cox J, Mota J, Sukupolvi-Petty S, Diamond MS, Rico-Hesse R. Mosquito bite delivery of dengue virus enhances immunogenicity and pathogenesis in humanized mice. J Virol. 2012;86:7637-49.

7. Frias-Staheli N, Dorner M, Marukian S, Billerbeck E, Labitt RN, Rice CM, Ploss A. Utility of humanized BLT mice for analysis of dengue virus infection and antiviral drug testing. J Virol. 2014;88:2205-18.

8. Fujiwara S, Imadome K, Takei M. Modeling EBV infection and pathogenesis in new-generation humanized mice. Exp Mol Med. 2015;47:e135.

9. Wang LX, Kang G, Kumar P, Lu W, Li Y, Zhou Y, Li Q, Wood C. HumanizedBLT mouse model of Kaposi's sarcoma-associated herpesvirus infection. Proc Natl Acad Sci USA. 2014;111:3146-51.

10. Kwant-Mitchell A, Ashkar AA, Rosenthal KL. Mucosal innate and adaptive immune responses against herpes simplex virus type 2 in a humanized mouse model. J Virol. 2009;83:10664-76. 
11. Hakki M, Goldman DC, Streblow DN, Hamlin KL, Krekylwich CN, Fleming WH, Nelson JA. HCMV infection of humanized mice after transplantation of G-CSF-mobilized peripheral blood stem cells from HCMV-seropositive donors. Biol Blood Marrow Transplant. 2014;20:132-5.

12. Tan CS, Broge TA Jr, Seung E, Vrbanac V, Viscidi R, Gordon J, Tager AM, Koralnik IJ. Detection of JC virus-specific immune responses in a novel humanized mouse model. PLOS ONE. 2013:8:e64313.

13. Kondo Y, Windrem MS, Zou L, Chandler-Militello D, Schanz SJ, Auvergne RM, Betstadt SJ, Harrington AR, Johnson M, Kazarov A, et al. Human glial chimeric mice reveal astrocytic dependence of JC virus infection. J Clin Invest. 2014;124:5323-36.

14. Song J, Willinger T, Rongvaux A, Eynon EE, Stevens S, Manz MG, Flavell RA, Galan JE. A mouse model for the human pathogen Salmonella typhi. Cell Host Microbe. 2010;8:369-76.

15. Li Y, Chen Q, Zheng D, Yin L, Chionh YH, Wong LH, Tan SQ, Tan TC, Chan JK, Alonso S, et al. Induction of functional human macrophages from bone marrow promonocytes by M-CSF in humanized mice. J Immunol. 2013;191:3192-9.

16. Walsh NC, Kenney LL, Jangalwe S, Aryee KE, Greiner DL, Brehm MA, Shultz LD. Humanized mouse models of clinical disease. Annu Rev Pathol. 2017;12:187-215.

17. Marsden MD, Zack JA. Humanized Mouse Models for Human Immunodeficiency Virus Infection. Annu Rev Virol. 2017;4:393-412.

18. Korner RW, Majjouti M, Alcazar MAA, Mahabir E. Of mice and men: The coronavirus MHV and mouse models as a translational approach to understand SARS-CoV-2. Viruses. 2020;12:880

19. Krishnakumar V, Durairajan SSK, Alagarasu K, Li M, Dash AP. Recent updates on mouse models for human immunodeficiency, influenza, and dengue viral infections. Viruses. 2019;11:252.

20. Morrison TE, Diamond MS. Animal models of zika virus infection, pathogenesis, and immunity. J Virol. 2017. https://doi.org/10.1128/ JVI.00009-17.

21. Zarebska-Michaluk D, Flisiak R, Flisiak-Jackiewicz M. Management of hepatitis $B$ and hepatitis $C$ coinfection: an expert review. Expert Rev Anti Infect Ther. 2020;18:1033-44.

22. Minkah NK, Schafer C, Kappe SHI. Humanized mouse models for the study of human malaria parasite biology, pathogenesis, and immunity. Front Immunol. 2018;9:807.

23. Tyagi RK, Tandel N, Deshpande R, Engelman RW, Patel SD, Tyagi P. Humanized mice are instrumental to the study of plasmodium falciparum infection. Front Immunol. 2018;9:2550.

24. Mosier DE, Gulizia RJ, Baird SM, Wilson DB. Transfer of a functional human immune system to mice with severe combined immunodeficiency. Nature. 1988;335:256-9.

25. Valbuena G, Halliday H, Borisevich V, Goez Y, Rockx B. A human lung xenograft mouse model of Nipah virus infection. PLoS Pathog. 2014;10:e1004063.

26. Ishikawa F, Yasukawa M, Lyons B, Yoshida S, Miyamoto T, Yoshimoto G, Watanabe T, Akashi K, Shultz LD, Harada M. Development of functional human blood and immune systems in NOD/SCID/IL2 receptor gamma chain(null) mice. Blood. 2005:106:1565-73.

27. Sarkar S, Heise MT. Mouse models as resources for studying infectious diseases. Clin Ther. 2019:41:1912-22.

28. Masopust D, Sivula CP, Jameson SC. Of mice, dirty mice, and men: using mice to understand human immunology. J Immunol. 2017;199:383-8.

29. Shultz LD, Brehm MA, Garcia-Martinez JV, Greiner DL. Humanized mice for immune system investigation: progress, promise and challenges. Nat Rev Immunol. 2012;12:786-98.

30. Shultz LD, Ishikawa F, Greiner DL. Humanized mice in translational biomedical research. Nat Rev Immunol. 2007;7:118-30.

31. Taube S, Kolawole AO, Hohne M, Wilkinson JE, Handley SA, Perry JW, Thackray LB, Akkina R, Wobus CE. A mouse model for human norovirus. MBio. 2013. https://doi.org/10.1128/mBio.00450-13.

32. Garrison AR, Smith DR, Golden JW. Animal models for crimean-congo hemorrhagic fever human disease. Viruses. 2019:11:590.

33. Grant A, Ponia SS, Tripathi S, Balasubramaniam V, Miorin L, Sourisseau M, Schwarz MC, Sanchez-Seco MP, Evans MJ, Best SM, Garcia-Sastre A. Zika virus targets human STAT2 to inhibit type I interferon signaling. Cell Host Microbe. 2016;19:882-90.
34. Peck KM, Cockrell AS, Yount BL, Scobey T, Baric RS, Heise MT. Glycosylation of mouse DPP4 plays a role in inhibiting Middle East respiratory syndrome coronavirus infection. J Virol. 2015;89:4696-9.

35. Cockrell AS, Yount BL, Scobey T, Jensen K, Douglas M, Beall A, Tang XC, Marasco WA, Heise MT, Baric RS. A mouse model for MERS coronavirus-induced acute respiratory distress syndrome. Nat Microbiol. 2016;2:16226.

36. Rall GF, Manchester M, Daniels LR, Callahan EM, Belman AR, Oldstone MB. A transgenic mouse model for measles virus infection of the brain. Proc Natl Acad Sci U S A. 1997:94:4659-63.

37. Li K, Wohlford-Lenane CL, Channappanavar R, Park JE, Earnest JT, Bair TB, Bates AM, Brogden KA, Flaherty HA, Gallagher T, et al. Mouse-adapted MERS coronavirus causes lethal lung disease in human DPP4 knockin mice. Proc Natl Acad Sci U S A. 2017;114:E3119-28.

38. Gaska JM, Balev M, Ding Q, Heller B, Ploss A. Differences across cyclophilin A orthologs contribute to the host range restriction of hepatitis $C$ virus. Elife. 2019;8:e44436.

39. Seydel KB, Li E, Swanson PE, Stanley SL Jr. Human intestinal epithelial cells produce proinflammatory cytokines in response to infection in a SCID mouse-human intestinal xenograft model of amebiasis. Infect Immun. 1997;65:1631-9.

40. Zschaler J, Schlorke D, Arnhold J. Differences in innate immune response between man and mouse. Crit Rev Immunol. 2014;34:433-54.

41. Theocharides AP, Rongvaux A, Fritsch K, Flavell RA, Manz MG. Humanized hemato-lymphoid system mice. Haematologica. 2016;101:5-19.

42. Lan P, Tonomura N, Shimizu A, Wang S, Yang YG. Reconstitution of a functional human immune system in immunodeficient mice through combined human fetal thymus/liver and CD34+ cell transplantation. Blood. 2006;108:487-92.

43. Melkus MW, Estes JD, Padgett-Thomas A, Gatlin J, Denton PW, Othieno FA, Wege AK, Haase AT, Garcia JV. Humanized mice mount specific adaptive and innate immune responses to EBV and TSST-1. Nat Med. 2006;12:1316-22.

44. Ai M, Curran MA. Immune checkpoint combinations from mouse to man. Cancer Immunol Immunother. 2015:64:885-92.

45. Watanabe Y, Takahashi T, Okajima A, Shiokawa M, Ishii N, Katano I, Ito R, Ito M, Minegishi M, Minegishi N, et al. The analysis of the functions of human $B$ and T cells in humanized NOD/shi-scid/gammac(null) (NOG) mice (hu-HSC NOG mice). Int Immunol. 2009;21:843-58.

46. Akkina R, Allam A, Balazs AB, Blankson JN, Burnett JC, Casares S, Garcia $J$ V, Hasenkrug KJ, Kashanchi F, Kitchen SG, et al. Improvements and limitations of humanized mouse models for HIV research: NIH/NIAID "Meet the Experts" 2015 Workshop Summary. AIDS Res Hum Retroviruses. 2016;32:109-19.

47. Bosma GC, Gibson DM, Custer RP, Bosma MJ. Reconstitution of scid mice by injection of varying numbers of normal fetal liver cells into scid neonates. Curr Top Microbiol Immunol. 1989:152:151-9.

48. Bosma MJ. The scid mutation: occurrence and effect. Curr Top Microbiol Immunol. 1989:152:3-9.

49. Macchiarini F, Manz MG, Palucka AK, Shultz LD. Humanized mice: are we there yet? J Exp Med. 2005;202:1307-11.

50. Victor Garcia J. Humanized mice for HIV and AIDS research. Curr Opin Virol. 2016;19:56-64.

51. Gorantla S, Sneller H, Walters L, Sharp JG, Pirruccello SJ, West JT, Wood C, Dewhurst S, Gendelman HE, Poluektova L. Human immunodeficiency virus type 1 pathobiology studied in humanized BALB/C-Rag2-/-gammac-/- mice. J Virol. 2007:81:2700-12.

52. Gorantla S, Gendelman HE, Poluektova LY. Can humanized mice reflect the complex pathobiology of HIV-associated neurocognitive disorders? J Neuroimmune Pharmacol. 2012;7:352-62.

53. Deruaz M, Luster AD. BLT humanized mice as model to study HIV vaginal transmission. J Infect Dis. 2013;208(Suppl 2):S131-136.

54. Karpel ME, Boutwell CL, Allen TM. BLT humanized mice as a small animal model of HIV infection. Curr Opin Virol. 2015:13:75-80.

55. Deruaz M, Tager AM. Humanized mouse models of latent HIV infection. Curr Opin Virol. 2017:25:97-104.

56. Llewellyn GN, Seclen E, Wietgrefe S, Liu S, Chateau M, Pei H, Perkey K, Marsden MD, Hinkley SJ, Paschon DE, et al. Humanized mouse model of HIV-1 latency with enrichment of latent virus in PD-1(+) and TIGIT(+) CD4 T Cells. J Virol. 2019;93(10):e02086-18. 
57. Su H, Cheng Y, Sravanam S, Mathews S, Gorantla S, Poluektova LY, Dash PK, Gendelman HE. Immune activations and viral tissue compartmentalization during progressive HIV-1 infection of humanized mice. Front Immunol. 2019;10:340.

58. Su H, Sravanam S, Gorantla S, Kaminski R, Khalili K, Poluektova L, Gendelman HE, Dash PK. Amplification of replication competent hiv-1 by adoptive transfer of human cells from infected humanized mice. Front Cell Infect Microbiol. 2020;10:38.

59. Arainga M, Edagwa B, Mosley RL, Poluektova LY, Gorantla S, Gendelman HE. A mature macrophage is a principal HIV-1 cellular reservoir in humanized mice after treatment with long acting antiretroviral therapy. Retrovirology. 2017;14:17.

60. Honeycutt JB, Thayer WO, Baker CE, Ribeiro RM, Lada SM, Cao Y, Cleary RA, Hudgens MG, Richman DD, Garcia JV. HIV persistence in tissue macrophages of humanized myeloid-only mice during antiretroviral therapy. Nat Med. 2017;23:638-43.

61. Goncalves BC, Lopes Barbosa MG, Silva Olak AP, Belebecha Terezo N, Nishi L, Watanabe MA, Marinello P, Zendrini Rechenchoski D, Dejato Rocha SP, Faccin-Galhardi LC. Antiviral therapies: advances and perspectives. Fundam Clin Pharmacol. 2020;35:305

62. Adalja A, Inglesby T. Broad-spectrum antiviral agents: A crucial pandemic tool. Expert Rev Anti Infect Ther. 2019;17:467-70.

63. Edagwa BJ, Gendelman HE. Antimicrobials: Broad-spectrum antivirals. Nat Mater. 2018;17:114-6.

64. Bollinger RC, Thio CL, Sulkowski MS, McKenzie-White J, Thomas DL, Flexner $C$. Addressing the global burden of hepatitis B virus while developing long-acting injectables for the prevention and treatment of HIV. Lancet HIV. 2020;7:e443-8.

65. Cobb DA, Smith NA, Edagwa BJ, McMillan JM. Long-acting approaches for delivery of antiretroviral drugs for prevention and treatment of HIV: a review of recent research. Expert Opin Drug Deliv. 2020;17:1227-38.

66. Gruell H, Klein F. Progress in HIV-1 antibody research using humanized mice. Curr Opin HIV AIDS. 2017;12:285-93.

67. Denton PW, Garcia JV. Novel humanized murine models for HIV research. Curr HIV/AIDS Rep. 2009;6:13-9.

68. Stoddart CA, Galkina SA, Joshi P, Kosikova G, Moreno ME, Rivera JM, Sloan B, Reeve AB, Sarafianos SG, Murphey-Corb M, Parniak MA. Oral administration of the nucleoside EFdA (4'-ethynyl-2-fluoro-2'-deoxyadenosine) provides rapid suppression of HIV viremia in humanized mice and favorable pharmacokinetic properties in mice and the rhesus macaque. Antimicrob Agents Chemother. 2015;59:4190-8.

69. Kovarova M, Swanson MD, Sanchez RI, Baker CE, Steve J, Spagnuolo RA, Howell BJ, Hazuda DJ, Garcia JV. A long-acting formulation of the integrase inhibitor raltegravir protects humanized BLT mice from repeated high-dose vaginal HIV challenges. J Antimicrob Chemother. 2016;71:1586-96.

70. Roy U, McMillan J, Alnouti Y, Gautum N, Smith N, Balkundi S, Dash P, Gorantla S, Martinez-Skinner A, Meza J, et al. Pharmacodynamic and antiretroviral activities of combination nanoformulated antiretrovirals in HIV-1-infected human peripheral blood lymphocyte-reconstituted mice. J Infect Dis. 2012;206:1577-88.

71. Dash PK, Gendelman HE, Roy U, Balkundi S, Alnouti Y, Mosley RL, Gelbard HA, McMillan J, Gorantla S, Poluektova LY. Long-acting nanoformulated antiretroviral therapy elicits potent antiretroviral and neuroprotective responses in HIV-1-infected humanized mice. AIDS. 2012;26:2135-44.

72. Puligujja P, Arainga M, Dash P, Palandri D, Mosley RL, Gorantla S, Poluektova L, McMillan J, Gendelman HE. Pharmacodynamics of folic acid receptor targeted antiretroviral nanotherapy in HIV-1-infected humanized mice. Antiviral Res. 2015;120:85-8.

73. Puligujja P, Balkundi SS, Kendrick LM, Baldridge HM, Hilaire JR, Bade AN, Dash PK, Zhang G, Poluektova LY, Gorantla S, et al. Pharmacodynamics of long-acting folic acid-receptor targeted ritonavir-boosted atazanavir nanoformulations. Biomaterials. 2015;41:141-50.

74. Zhou T, Su H, Dash P, Lin Z, Dyavar Shetty BL, Kocher T, Szlachetka A, Lamberty B, Fox HS, Poluektova L, et al. Creation of a nanoformulated cabotegravir prodrug with improved antiretroviral profiles. Biomaterials. 2018;151:53-65.

75. Sillman B, Bade AN, Dash PK, Bhargavan B, Kocher T, Mathews S, Su H, Kanmogne GD, Poluektova LY, Gorantla S, et al. Creation of a longacting nanoformulated dolutegravir. Nat Commun. 2018;9:443.
76. Kulkarni TA, Bade AN, Sillman B, Shetty BLD, Wojtkiewicz MS, Gautam N, Hilaire JR, Sravanam S, Szlachetka A, Lamberty BG, et al. A year-long extended release nanoformulated cabotegravir prodrug. Nat Mater. 2020;19:910-20.

77. Pardi N, Secreto AJ, Shan X, Debonera F, Glover J, Yi Y, Muramatsu H, N $H$, Mui BL, Tam YK, et al. Administration of nucleoside-modified mRNA encoding broadly neutralizing antibody protects humanized mice from HIV-1 challenge. Nat Commun. 2017:8:14630.

78. Koenig S, Gendelman HE, Orenstein JM, Dal Canto MC, Pezeshkpour GH, Yungbluth M, Janotta F, Aksamit A, Martin MA, Fauci AS. Detection of AIDS virus in macrophages in brain tissue from AIDS patients with encephalopathy. Science. 1986;233:1089-93.

79. Sillman B, Woldstad C, McMillan J, Gendelman HE. Neuropathogenesis of human immunodeficiency virus infection. Handb Clin Neurol. 2018;152:21-40.

80. Gannon P, Khan MZ, Kolson DL. Current understanding of HIVassociated neurocognitive disorders pathogenesis. Curr Opin Neurol. 2011;24:275-83.

81. Kranick SM, Nath A. Neurologic complications of HIV-1 infection and its treatment in the era of antiretroviral therapy. Continuum (Minneap Minn). 2012;18:1319-37.

82. Autran B, Descours B, Bacchus C. Immune control of HIV-1 reservoirs. Curr Opin HIV AIDS. 2013;8:204-10.

83. Fenwick C, Joo V, Jacquier P, Noto A, Banga R, Perreau M, Pantaleo G. T-cell exhaustion in HIV infection. Immunol Rev. 2019;292:149-63.

84. Wong ME, Jaworowski A, Hearps AC. The HIV Reservoir in Monocytes and Macrophages. Front Immunol. 2019;10:1435.

85. Tyor WR, Power C, Gendelman HE, Markham RB. A model of human immunodeficiency virus encephalitis in scid mice. Proc Natl Acad Sci U S A. 1993;90:8658-62.

86. Persidsky Y, Gendelman HE. Murine models for human immunodeficiency virus type 1-associated dementia: the development of new treatment testing paradigms. J Neurovirol. 2002;8(Suppl 2):49-52.

87. Gorantla S, Poluektova L, Gendelman HE. Rodent models for HIVassociated neurocognitive disorders. Trends Neurosci. 2012;35:197-208.

88. Potula R, Poluektova L, Knipe B, Chrastil J, Heilman D, Dou H, Takikawa O, Munn DH, Gendelman HE, Persidsky Y. Inhibition of indoleamine 2,3-dioxygenase (IDO) enhances elimination of virus-infected macrophages in an animal model of HIV-1 encephalitis. Blood. 2005;106:2382-90.

89. Dash PK, Gorantla S, Gendelman HE, Knibbe J, Casale GP, Makarov E, Epstein AA, Gelbard HA, Boska MD, Poluektova LY. Loss of neuronal integrity during progressive HIV-1 infection of humanized mice. J Neurosci. 2011;31:3148-57.

90. Gorantla S, Makarov E, Finke-Dwyer J, Castanedo A, Holguin A, Gebhart $\mathrm{CL}$, Gendelman HE, Poluektova L. Links between progressive HIV-1 infection of humanized mice and viral neuropathogenesis. Am J Pathol. 2010;177:2938-49.

91. Boska MD, Dash PK, Knibbe J, Epstein AA, Akhter SP, Fields N, High R, Makarov E, Bonasera S, Gelbard HA, et al. Associations between brain microstructures, metabolites, and cognitive deficits during chronic HIV-1 infection of humanized mice. Mol Neurodegener. 2014;9:58.

92. Casas R, Muthusamy S, Wakim PG, Sinharay S, Lentz MR, Reid WC, Hammoud DA. MR brain volumetric measurements are predictive of neurobehavioral impairment in the HIV-1 transgenic rat. Neuroimage Clin. 2018;17:659-66.

93. McLaurin KA, Booze RM, Mactutus CF. Evolution of the HIV-1 transgenic rat: utility in assessing the progression of HIV-1-associated neurocognitive disorders. J Neurovirol. 2018;24:229-45.

94. Reid WC, Ibrahim WG, Kim SJ, Denaro F, Casas R, Lee DE, Maric D, Hammoud DA. Characterization of neuropathology in the HIV-1 transgenic rat at different ages. J Neuroimmunol. 2016;292:116-25.

95. Maung R, Hoefer MM, Sanchez AB, Sejbuk NE, Medders KE, Desai MK, Catalan IC, Dowling CC, de Rozieres CM, Garden GA, et al. CCR5 knockout prevents neuronal injury and behavioral impairment induced in a transgenic mouse model by a CXCR4-using HIV-1 glycoprotein 120. J Immunol. 2014;193:1895-910.

96. Repunte-Canonigo V, Lefebvre C, George O, Kawamura T, Morales M, Koob GF, Califano A, Masliah E, Sanna PP. Gene expression changes consistent with neuroAIDS and impaired working memory in HIV-1 transgenic rats. Mol Neurodegener. 2014;9:26. 
97. Paris JJ, Singh HD, Ganno ML, Jackson P, McLaughlin JP. Anxietylike behavior of mice produced by conditional central expression of the HIV-1 regulatory protein. Tat Psychopharmacology (Berl). 2014;231:2349-60.

98. Gu CJ, Borjabad A, Hadas E, Kelschenbach J, Kim BH, Chao W, Arancio $\mathrm{O}$, Suh J, Polsky B, McMillan J, et al. EcoHIV infection of mice establishes latent viral reservoirs in T cells and active viral reservoirs in macrophages that are sufficient for induction of neurocognitive impairment. PLoS Pathog. 2018;14:e1007061.

99. Kelschenbach J, He H, Kim BH, Borjabad A, Gu CJ, Chao W, Do M, Sharer $\mathrm{LR}$, Zhang $\mathrm{H}$, Arancio $\mathrm{O}$, et al. Efficient expression of HIV in immunocompetent mouse brain reveals a novel nonneurotoxic viral function in hippocampal synaptodendritic injury and memory impairment. MBio. 2019;10(4):e00591-19.

100. Li H, McLaurin KA, Mactutus CF, Booze RM. A rat model of EcoHIV brain infection. J Vis Exp. 2021. https://doi.org/10.3791/62137.

101. Honeycutt JB, Liao B, Nixon CC, Cleary RA, Thayer WO, Birath SL, Swanson MD, Sheridan P, Zakharova O, Prince F, et al. T cells establish and maintain CNS viral infection in HIV-infected humanized mice. J Clin Invest. 2018:128:2862-76.

102. Honeycutt JB, Sheridan PA, Matsushima GK, Garcia JV. Humanized mouse models for HIV-1 infection of the CNS. J Neurovirol. 2015;21:301-9.

103. Cenker JJ, Stultz RD, McDonald D. Brain microglial cells are highly susceptible to HIV-1 infection and spread. AIDS Res Hum Retroviruses. 2017;33:1155-65.

104. Wallet C, De Rovere M, Van Assche J, Daouad F, De Wit S, Gautier V, MalIon PWG, Marcello A, Van Lint C, Rohr O, Schwartz C. Microglial cells: the main HIV-1 reservoir in the brain. Front Cell Infect Microbiol. 2019;9:362.

105. Li W, Gorantla S, Gendelman HE, Poluektova LY. Systemic HIV-1 infection produces a unique glial footprint in humanized mouse brains. Dis Model Mech. 2017;10:1489-502.

106. Mathews S, Branch Woods A, Katano I, Makarov E, Thomas MB, Gendelman HE, Poluektova LY, Ito M, Gorantla S. Human Interleukin-34 facilitates microglia-like cell differentiation and persistent HIV-1 infection in humanized mice. Mol Neurodegener. 2019;14:12.

107. Seneviratne HK, Hamlin AN, Heck CJS, Bumpus NN. Spatial Distribution profiles of emtricitabine, tenofovir, efavirenz, and rilpivirine in murine tissues following in vivo dosing correlate with their safety profiles in humans. ACS Pharmacol Transl Sci. 2020;3:655-65.

108. De Benedetto I, Trunfio M, Guastamacchia G, Bonora S, Calcagno A. A review of the potential mechanisms of neuronal toxicity associated with antiretroviral drugs. J Neurovirol. 2020;26:642-51.

109. Ryan SK, Gonzalez MV, Garifallou JP, Bennett FC, Williams KS, Sotuyo NP, Mironets E, Cook K, Hakonarson H, Anderson SA, Jordan-Sciutto KL. Neuroinflammation and EIF2 signaling persist despite antiretroviral treatment in an hiPSC Tri-culture model of HIV infection. Stem Cell Reports. 2020;14:703-16.

110. Cheney L, Guzik H, Macaluso FP, Macian F, Cuervo AM, Berman JW. HIV Nef and antiretroviral therapy have an inhibitory effect on autophagy in human astrocytes that may contribute to HIV-associated neurocognitive disorders. Cells. 2020. https://doi.org/10.3390/cells9061426.

111. Jordan-Sciutto KL. Effects of antiretroviral therapy in the central nervous system: beyond viral suppression. J Neuroimmune Pharmacol. 2021;16:71-3.

112. Giunta B, Ehrhart J, Obregon DF, Lam L, Le L, Jin J, Fernandez F, Tan J, Shytle RD. Antiretroviral medications disrupt microglial phagocytosis of beta-amyloid and increase its production by neurons: implications for HIV-associated neurocognitive disorders. Mol Brain. 2011;4:23.

113. Fields JA, Spencer B, Swinton M, Qvale EM, Marquine MJ, Alexeeva A, Gough S, Soontornniyomkij B, Valera E, Masliah E, et al. Alterations in brain TREM2 and Amyloid-beta levels are associated with neurocognitive impairment in HIV-infected persons on antiretroviral therapy. J Neurochem. 2018;147:784-802.

114. Hategan A, Masliah E, Nath A. HIV and Alzheimer's disease: complex interactions of HIV-Tat with amyloid beta peptide and Tau protein. J Neurovirol. 2019;25:648-60.

115. Wang W, Smith N, Makarov E, Sun Y, Gebhart CL, Ganesan M, Osna NA, Gendelman HE, Edagwa BJ, Poluektova LY. A long-acting 3TC ProTide nanoformulation suppresses HBV replication in humanized mice. Nanomedicine. 2020;28:102185.
116. McMillan JM, Cobb DA, Lin Z, Banoub MG, Dagur RS, Branch Woods AA, Wang W, Makarov E, Kocher T, Joshi PS, et al. Antiretroviral drug metabolism in humanized PXR-CAR-CYP3A-NOG Mice. J Pharmacol Exp Ther. 2018;365:272-80.

117. Dagur RS, Wang W, Cheng Y, Makarov E, Ganesan M, Suemizu H, Gebhart CL, Gorantla S, Osna N, Poluektova LY. Human hepatocyte depletion in the presence of HIV-1 infection in dual reconstituted humanized mice. Biol Open. 2018;7(2):bio029785.

118. Gnanadhas DP, Dash PK, Sillman B, Bade AN, Lin Z, Palandri DL, Gautam N, Alnouti Y, Gelbard HA, McMillan J, et al. Autophagy facilitates macrophage depots of sustained-release nanoformulated antiretroviral drugs. J Clin Invest. 2017;127:857-73.

119. Llewellyn GN, Alvarez-Carbonell D, Chateau M, Karn J, Cannon PM. HIV-1 infection of microglial cells in a reconstituted humanized mouse model and identification of compounds that selectively reverse HIV latency. J Neurovirol. 2018;24:192-203.

120. Indolfi G, Easterbrook P, Dusheiko G, Siberry G, Chang MH, Thorne C, Bulterys M, Chan PL, El-Sayed MH, Giaquinto C, et al. Hepatitis B virus infection in children and adolescents. Lancet Gastroenterol Hepatol. 2019:4:466-76.

121. Bosh KA, Coyle JR, Hansen V, Kim EM, Speers S, Comer M, Maddox LM, Khuwaja S, Zhou W, Jatta A, et al. HIV and viral hepatitis coinfection analysis using surveillance data from 15 US states and two cities. Epidemiol Infect. 2018;146:920-30.

122. Sema Baltazar C, Kellogg TA, Boothe M, Loarec A, de Abreu E, Condula M, Fazito E, Raymond HF, Temmerman M, Luchters S. Prevalence of HIV, viral hepatitis $\mathrm{B} / \mathrm{C}$ and tuberculosis and treatment outcomes among people who use drugs: Results from the implementation of the first drop-in-center in Mozambique. Int J Drug Policy. 2021;90:103095.

123. Tang A, Hallouch O, Chernyak V, Kamaya A, Sirlin CB. Epidemiology of hepatocellular carcinoma: target population for surveillance and diagnosis. Abdom Radiol (NY). 2018;43:13-25.

124. Allweiss $L$, Strick-Marchand $H$. In-vitro and in-vivo models for hepatitis $B$ cure research. Curr Opin HIV AIDS. 2020;15:173-9.

125. Dandri M, Burda MR, Torok E, Pollok JM, Iwanska A, Sommer G, Rogiers X, Rogler CE, Gupta S, Will H, et al. Repopulation of mouse liver with human hepatocytes and in vivo infection with hepatitis B virus. Hepatology. 2001;33:981-8.

126. Mercer DF, Schiller DE, Elliott JF, Douglas DN, Hao C, Rinfret A, Addison WR, Fischer KP, Churchill TA, Lakey JR, et al. Hepatitis $C$ virus replication in mice with chimeric human livers. Nat Med. 2001;7:927-33.

127. Azuma H, Paulk N, Ranade A, Dorrell C, Al-Dhalimy M, Ellis E, Strom S, Kay MA, Finegold M, Grompe M. Robust expansion of human hepatocytes in Fah-/-/Rag2-/-/II2rg-/- mice. Nat Biotechnol. 2007;25:903-10.

128. Hasegawa M, Kawai K, Mitsui T, Taniguchi K, Monnai M, Wakui M, Ito M, Suematsu M, Peltz G, Nakamura M, Suemizu H. The reconstituted "humanized liver" in TK-NOG mice is mature and functional. Biochem Biophys Res Commun. 2011;405:405-10.

129. Tateno C, Kojima Y. Characterization and applications of chimeric mice with humanized livers for preclinical drug development. Lab Anim Res. 2020;36:2.

130. Billich A. Entecavir (Bristol-Myers Squibb). Curr Opin Investig Drugs. 2001:2:617-21.

131. Murakami E, Tsuge M, Hiraga N, Kan H, Uchida T, Masaki K, Nakahara T, Ono A, Miki D, Kawaoka T, et al. Effect of tenofovir disoproxil fumarate on drug-resistant HBV clones. J Infect. 2016;72:91-102.

132. Tsuge M, Uchida T, Hiraga N, Kan H, Makokha GN, Abe-Chayama H, Miki D, Imamura M, Ochi H, Hayes CN, et al. Development of a novel site-specific pegylated interferon beta for antiviral therapy of chronic hepatitis B virus. Antimicrob Agents Chemother. 2017;61(6):e00183-17.

133. Allweiss L, Giersch K, Pirosu A, Volz T, Muench RC, Beran RK, Urban S, Javanbakht H, Fletcher SP, Lutgehetmann M, Dandri M. Therapeutic shutdown of HBV transcripts promotes reappearance of the SMC5/6 complex and silencing of the viral genome in vivo. Gut. 2021. https:// doi.org/10.1136/gutjnl-2020-322571.

134. Uchida T, Imamura M, Hayes CN, Hiraga N, Kan H, Tsuge M, Abe-Chayama H, Zhang Y, Makokha GN, Aikata H, et al. Persistent loss of hepatitis $B$ virus markers in serum without cellular immunity by combination of peginterferon and entecavir therapy in humanized mice. Antimicrob Agents Chemother. 2017. https://doi.org/10.1128/AAC.00725-17. 
135. Tateno C, Kawase Y, Tobita Y, Hamamura S, Ohshita H, Yokomichi H, Sanada H, Kakuni M, Shiota A, Kojima Y, et al. Generation of novel chimeric mice with humanized livers by using hemizygous CDNA-uPA/ SCID mice. PLOS ONE. 2015;10:0142145.

136. Ye X, Tateno C, Thi EP, Kakuni M, Snead NM, Ishida Y, Barnard TR, Sofia MJ, Shimada T, Lee ACH. Hepatitis B virus therapeutic agent ARB-1740 has inhibitory effect on hepatitis delta virus in a new dually-infected humanized mouse model. ACS Infect Dis. 2019;5:738-49.

137. Sato Y, Matsui H, Yamamoto N, Sato R, Munakata T, Kohara M, Harashima $H$. Highly specific delivery of siRNA to hepatocytes circumvents endothelial cell-mediated lipid nanoparticle-associated toxicity leading to the safe and efficacious decrease in the hepatitis B virus. J Control Release. 2017;266:216-25.

138. Kang JA, Kim S, Park M, Park HJ, Kim JH, Park S, Hwang JR, Kim YC, Jun Kim Y, Cho Y, et al. Ciclopirox inhibits hepatitis B Virus secretion by blocking capsid assembly. Nat Commun. 2019;10:2184

139. Amblard F, Boucle S, Bassit L, Cox B, Sari O, Tao S, Chen Z, Ozturk T, Verma K, Russell O, et al. Novel Hepatitis B virus capsid assembly modulator induces potent antiviral responses in vitro and in humanized mice. Antimicrob Agents Chemother. 2020. https://doi.org/10.1128/AAC. 01701-19.

140. Klumpp K, Shimada T, Allweiss L, Volz T, Lutgehetmann M, Hartman G, Flores OA, Lam AM, Dandri M. Efficacy of NVR 3-778, alone and in combination with pegylated interferon, vs entecavir In UPA/SCID mice With humanized livers and HBV infection. Gastroenterology. 2018;154:652662 e658

141. Stone D, Long KR, Loprieno MA, De Silva Feelixge HS, Kenkel EJ, Liley RM, Rapp S, Roychoudhury P, Nguyen T, Stensland L, et al. CRISPR-Cas9 gene editing of hepatitis B virus in chronically infected humanized mice. Mol Ther Methods Clin Dev. 2021;20:258-75.

142. Kayesh MEH, Amako Y, Hashem MA, Murakami S, Ogawa S, Yamamoto N, Hifumi T, Miyoshi N, Sugiyama M, Tanaka Y, et al. Development of an in vivo delivery system for CRISPR/Cas9-mediated targeting of hepatitis B virus cccDNA. Virus Res. 2020;290:198191.

143. Wisskirchen K, Kah J, Malo A, Asen T, Volz T, Allweiss L, Wettengel JM, Lutgehetmann M, Urban S, Bauer T, et al. T cell receptor grafting allows virological control of Hepatitis B virus infection. J Clin Invest. 2019:129:2932-45.

144. Maravelia P, Frelin L, Ni Y, Caro Perez N, Ahlen G, Jagya N, Verch G, Verhoye $L$, Pater $L$, Johansson $M$, et al. Blocking entry of hepatitis $B$ and $D$ viruses to hepatocytes as a novel immunotherapy for treating chronic infections. J Infect Dis. 2021;223:128-38.

145. Strich JR, Chertow DS. CRISPR-Cas Biology and Its Application to Infectious Diseases. J Clin Microbiol. 2019. https://doi.org/10.1128/JCM. 01307-18.

146. Cai L, Fisher AL, Huang H, Xie Z. CRISPR-mediated genome editing and human diseases. Genes Dis. 2016;3:244-51.

147. Tycko J, Myer VE, Hsu PD. Methods for optimizing CRISPR-Cas9 genome editing specificity. Mol Cell. 2016;63:355-70.

148. Wang H, Yang H, Shivalila CS, Dawlaty MM, Cheng AW, Zhang F, Jaenisch R. One-step generation of mice carrying mutations in multiple genes by CRISPR/Cas-mediated genome engineering. Cell. 2013;153:910-8

149. Park CY, Kim DH, Son JS, Sung JJ, Lee J, Bae S, Kim JH, Kim DW, Kim JS. Functional correction of large factor VIII gene chromosomal inversions in hemophilia a patient-derived iPSCs using CRISPR-Cas9. Cell Stem Cell. 2015;17:213-20.

150. Zhu F, Nair RR, Fisher EMC, Cunningham TJ. Humanising the mouse genome piece by piece. Nat Commun. 1845;2019:10.

151. Onos KD, Sukoff Rizzo SJ, Howell GR, Sasner M. Toward more predictive genetic mouse models of Alzheimer's disease. Brain Res Bull. 2016;122:1-11.

152. Dash PK, Kaminski R, Bella R, Su H, Mathews S, Ahooyi TM, Chen C, Mancuso P, Sariyer R, Ferrante P, et al. Sequential LASER ART and CRISPR treatments eliminate HIV-1 in a subset of infected humanized mice. Nat Commun. 2019;10:2753.

153. Xiao Q, Chen S, Wang Q, Liu Z, Liu S, Deng H, Hou W, Wu D, Xiong Y, Li J, Guo D. CCR5 editing by Staphylococcus aureus Cas9 in human primary CD4(+) T cells and hematopoietic stem/progenitor cells promotes HIV-1 resistance and CD4(+)T cell enrichment in humanized mice. Retrovirology. 2019;16:15.
154. Morgan DG, Mielke MM. Knowledge gaps in Alzheimer's disease immune biomarker research. Alzheimers Dement. 2021. https:// doi.org/10.1002/alz.12342.

155. Machhi J, Kevadiya BD, Muhammad IK, Herskovitz J, Olson KE, Mosley $\mathrm{RL}$, Gendelman HE. Harnessing regulatory T cell neuroprotective activities for treatment of neurodegenerative disorders. Mol Neurodegener. 2020;15:32.

156. Massoud F, Gauthier S. Update on the pharmacological treatment of Alzheimer's disease. Curr Neuropharmacol. 2010;8:69-80.

157. Saito T, Matsuba Y, Mihira N, Takano J, Nilsson P, Itohara S, Iwata N, Saido TC. Single App knock-in mouse models of Alzheimer's disease. Nat Neurosci. 2014;17:661-3.

158. Masuda T, Sankowski R, Staszewski O, Bottcher C, Amann L, Sagar, Scheiwe C, Nessler S, Kunz P, van Loo G, et al. Spatial and temporal heterogeneity of mouse and human microglia at single-cell resolution. Nature. 2019;566:388-392.

159. Fyfe I. Mouse brains, human microglia. Nat Rev Neurol. 2019;15:558-9.

160. Espuny-Camacho I, Arranz AM, Fiers M, Snellinx A, Ando K, Munck S, Bonnefont J, Lambot L, Corthout N, Omodho L, et al. Hallmarks of alzheimer's disease in stem-cell-derived human neurons transplanted into mouse brain. Neuron. 2017;93:1066-1081e1068.

161. Hasselmann J, Coburn MA, England W, Figueroa Velez DX, Kiani Shabestari S, Tu CH, McQuade A, Kolahdouzan M, Echeverria K, Claes C, et al. Development of a Chimeric Model to Study and Manipulate Human Microglia In Vivo. Neuron. 2019;103:1016-1033 e1010.

162. BjornsonHooper ZB, Fragiadakis GK, Spitzer MH, Madhireddy D, Mcllwain D, Nolan GP. A comprehensive atlas of immunological differences between humans, mice and non-human primates. BioRxiv. 2019. https://doi.org/10.1101/574160.

163. Mestas J, Hughes CC. Of mice and not men: differences between mouse and human immunology. J Immunol. 2004:172:2731-8.

164. Lin JG, Chen CJ, Yang HB, Chen YH, Hung SY. Electroacupuncture promotes recovery of motor function and reduces dopaminergic neuron degeneration in rodent models of Parkinson's disease. Int J Mol Sci. 2017. https://doi.org/10.3390/ijms18091846.

165. Scarffe LA, Stevens DA, Dawson VL, Dawson TM. Parkin and PINK1: much more than mitophagy. Trends Neurosci. 2014;37:315-24.

166. Conway KA, Harper JD, Lansbury PT. Accelerated in vitro fibril formation by a mutant alpha-synuclein linked to early-onset Parkinson disease. Nat Med. 1998:4:1318-20.

167. Conway KA, Lee SJ, Rochet JC, Ding TT, Williamson RE, Lansbury PT Jr. Acceleration of oligomerization, not fibrillization, is a shared property of both alpha-synuclein mutations linked to early-onset Parkinson's disease: implications for pathogenesis and therapy. Proc Natl Acad Sci U S A. 2000;97:571-6.

168. Fusco G, Chen SW, Williamson PTF, Cascella R, Perni M, Jarvis JA, Cecchi C, Vendruscolo M, Chiti F, Cremades N, et al. Structural basis of membrane disruption and cellular toxicity by a-synuclein oligomers. Science. 2017:358:1440-3.

169. Goedert M, Spillantini MG, Del Tredici K, Braak H. 100 years of Lewy pathology. Nat Rev Neurol. 2013;9:13-24.

170. Manocha GD, Floden AM, Puig KL, Nagamoto-Combs K, Scherzer CR, Combs CK. Defining the contribution of neuroinflammation to Parkinson's disease in humanized immune system mice. Mol Neurodegener. 2017;12:17.

171. Liu J, Albers MW, Wandless TJ, Luan S, Alberg DG, Belshaw PJ, Cohen P, Mackintosh C, Klee CB, Schreiber SL. Inhibition of T cell signaling by immunophilin-ligand complexes correlates with loss of calcineurin phosphatase activity. Biochemistry. 1992;31:3896-901.

172. Liu J, Farmer JD Jr, Lane WS, Friedman J, Weissman I, Schreiber SL. Calcineurin is a common target of cyclophilin-cyclosporin A and FKBPFK506 complexes. Cell. 1991;66:807-15.

173. Gerard M, Deleersnijder A, Daniëls V, Schreurs S, Munck S, Reumers V, Pottel H, Engelborghs $Y$, Van den Haute C, Taymans JM, et al. Inhibition of FK506 binding proteins reduces alpha-synuclein aggregation and Parkinson's disease-like pathology. J Neurosci. 2010;30:2454-63.

174. Deleersnijder A, Van Rompuy AS, Desender L, Pottel H, Buée L, Debyser Z, Baekelandt V, Gerard M. Comparative analysis of different peptidyl-prolyl isomerases reveals FK506-binding protein 12 as the most potent enhancer of alpha-synuclein aggregation. J Biol Chem. 2011:286:26687-701. 
175. Kitamura Y, Itano Y, Kubo T, Nomura Y. Suppressive effect of FK-506, a novel immunosuppressant, against MPTP-induced dopamine depletion in the striatum of young C57BL/6 mice. J Neuroimmunol. 1994;50:221-4.

176. Cardoso SW, Torres TS, Santini-Oliveira M, Marins LM, Veloso VG, Grinsztejn B. Aging with HIV: a practical review. Braz J Infect Dis. 2013;17:464-79.

177. Wing EJ. HIV and aging. Int J Infect Dis. 2016;53:61-8.

178. Nookala AR, Mitra J, Chaudhari NS, Hegde ML, Kumar A. An overview of human immunodeficiency virus type 1-associated common neurological complications: Does aging pose a challenge? J Alzheimers Dis. 2017;60:S169-s193.

179. Elicer IM, Byrd D, Clark US, Morgello S, Robinson-Papp J. Motor function declines over time in human immunodeficiency virus and is associated with cerebrovascular disease, while HIV-associated neurocognitive disorder remains stable. J Neurovirol. 2018;24:514-22.

180. Muller-Oehring EM, Fama R, Levine TF, Hardcastle C, Goodcase R, Martin T, Prabhakar V, Bronte-Stewart HM, Poston KL, Sullivan EV, Schulte T. Cognitive and motor deficits in older adults with HIV infection: Comparison with normal ageing and Parkinson's disease. J Neuropsychol. 2020;5:253-273.

181. Olson KE, Bade AN, Schutt CR, Dong J, Shandler SJ, Boska MD, Mosley RL, Gendelman HE, Liu Y. Manganese-enhanced magnetic resonance imaging for detection of vasoactive intestinal peptide receptor 2 agonist therapy in a model of Parkinson's disease. Neurotherapeutics. 2016;13:635-46.
182. Ben-Nun A, Kaushansky N, Kawakami N, Krishnamoorthy G, Berer K, Liblau R, Hohlfeld R, Wekerle H. From classic to spontaneous and humanized models of multiple sclerosis: impact on understanding pathogenesis and drug development. J Autoimmun. 2014;54:33-50.

183. Devoy A, Bunton-Stasyshyn RK, Tybulewicz VL, Smith AJ, Fisher EM. Genomically humanized mice: technologies and promises. Nat Rev Genet. 2011;13:14-20.

184. Prasad EM, Hung S-Y. Behavioral Tests in Neurotoxin-Induced Animal Models of Parkinson's Disease. Antioxidants (Basel) 2020;9(10):1007.

185. Bagga P, Chugani AN, Patel AB. Neuroprotective effects of caffeine in MPTP model of Parkinson's disease: A (13)C NMR study. Neurochem Int. 2016;92:25-34.

186. Zhang W, He H, Song H, Zhao J, Li T, Wu L, Zhang X, Chen J. Neuroprotective effects of salidroside in the MPTP mouse model of parkinson's disease: involvement of the PI3K/Akt/GSK3beta pathway. Parkinsons Dis. 2016;2016:9450137.

187. Hutter-Saunders JA, Gendelman HE, Mosley RL. Murine motor and behavior functional evaluations for acute 1-methyl-4-phenyl-1,2,3,6tetrahydropyridine (MPTP) intoxication. J Neuroimmune Pharmacol. 2012;7:279-88.

\section{Publisher's Note}

Springer Nature remains neutral with regard to jurisdictional claims in published maps and institutional affiliations.
Ready to submit your research? Choose BMC and benefit from:

- fast, convenient online submission

- thorough peer review by experienced researchers in your field

- rapid publication on acceptance

- support for research data, including large and complex data types

- gold Open Access which fosters wider collaboration and increased citations

- maximum visibility for your research: over $100 \mathrm{M}$ website views per year

At BMC, research is always in progress.

Learn more biomedcentral.com/submissions 